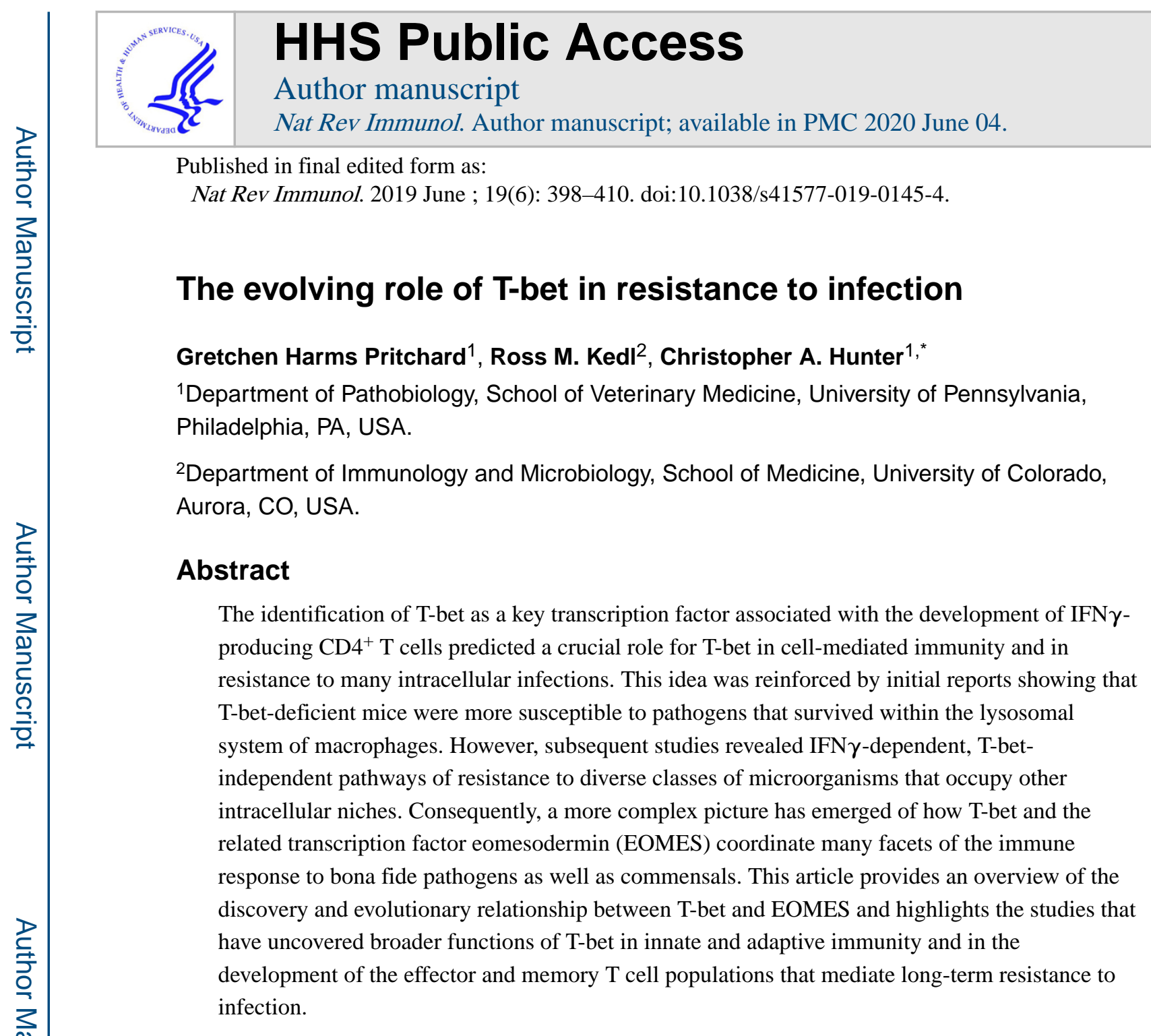

A major theme in immunology for the past 50 years has been the study of the functional and phenotypic diversity of $\mathrm{T}$ cell subsets and their role in protective or pathological responses. $\mathrm{T}$ cells as distinct thymus-derived lymphoc ytes were first described, albeit controversially, in the $1960 \mathrm{~s}^{1,2}$ and within a few years were accepted as a population distinct from antibodyproducing lymphocytes ${ }^{3}$. These lymphocytes could be further divided into those that helped B cells $\left(C D 4^{+} \mathrm{T}\right.$ cells $)$ and those that were cytotoxic $\left(\mathrm{CD}^{+} \mathrm{T} \text { cells }\right)^{4}$. By the 1980 s it was appreciated that different subsets of $\mathrm{CD} 4^{+} \mathrm{T}$ helper $\left(\mathrm{T}_{\mathrm{H}}\right)$ cells predominantly produced either IFN $\gamma$ (in the case of $\mathrm{T}_{\mathrm{H}} 1$ cells) or the combination of IL-4 and IL-5 (in the case of $\mathrm{T}_{\mathrm{H}} 2$ cells $)^{5}$. The distinct functions of these subsets were highlighted by studies in which $\mathrm{CD}^{+} \mathrm{T}$ cell production of $\mathrm{IFN} \gamma$ was required to activate the antimicrobial activities of

\footnotetext{
* chunter@vet.upenn.edu.

Author contributions

C.A.H. and G.H.P. contributed to researching data, discussion of content and the writing, review and editing of this manuscript.

R.M.K. contributed to discussion of content and the review and editing of the manuscript.

Competing interests

The authors declare no competing interests.

Publisher's note

Springer Nature remains neutral with regard to jurisdictional claims in published maps and institutional affiliations.
} 
macrophages that are central to resistance to intracellular infections, whereas $\mathrm{CD} 4^{+} \mathrm{T}$ cells that produce IL-4 promoted resistance to helminth parasites ${ }^{6}$. Since then, as predicted by Mosmann and Coffman, additional subsets of functionally diverse $\mathrm{T}$ cells have been described that include regulatory $\mathrm{T}\left(\mathrm{T}_{\mathrm{reg}}\right)$ cells ${ }^{7}, \mathrm{~T}_{\mathrm{H}} 17$ cells $^{8}$ and $\mathrm{T}$ follicular helper $\left(\mathrm{T}_{\mathrm{FH}}\right)$ cells 9 .

While distinct $\mathrm{T}$ cell subsets could be associated with resistance to different classes of pathogens, there was also the realization that aberrant $\mathrm{T}$ cell activity contributes to inflammatory and autoimmune conditions ${ }^{10-13}$. In order to be able to manipulate the immune response to better manage immune-mediated conditions, or promote $\mathrm{T}$ cell responses in the context of infection or vaccination, it was necessary to understand the molecular mechanisms that control T cell differentiation. In the 1990s, the ability of the transcription factors MAF and GATA3 to direct the generation of $\mathrm{T}_{\mathrm{H}} 2$ cell responses was described $^{14,15}$, and in 2000, the transcription factor T-bet, encoded by the gene $T b \times 21$, was identified as a key regulator of $\mathrm{T}_{\mathrm{H}} 1$ cell responses ${ }^{16}$. Over the next decade, there were numerous examples of transcription factors that could be linked to individual $\mathrm{T}$ cell subsets: forkhead box protein $\mathrm{P} 3$ (FOXP3) is essential for the development and function of $\mathrm{T}_{\text {reg }}$ cells ${ }^{17,18}, \mathrm{~T}_{\mathrm{H}} 17$ cells require ROR $\gamma \mathrm{t}^{19}$, and BCL-6 directs the generation of $\mathrm{T}_{\mathrm{FH}}$ cells ${ }^{20-22}$.

The ability to link different transcription factors with specific $\mathrm{T}$ cell subsets provided a framework to understand the mechanisms that underlie the differentiation and plasticity of $\mathrm{T}$ cells and reinforced the idea that individual transcription factors (such as T-bet, GATA3, signal transducer and activator of transcription 4 (STAT4) and STAT6) could act as 'master regulators' of distinct $\mathrm{CD}^{+}{ }^{+} \mathrm{T}$ cell fates. This term was originally used to describe transcription factors that regulate developmental lineages ${ }^{23}$, but many of these so-called master regulators that are associated with discrete $\mathrm{T}$ cell subsets are often co-expressed and are not restricted to $\mathrm{CD} 4^{+} \mathrm{T}$ cells. In addition, variations in the signals propagated downstream of the $\mathrm{T}$ cell receptor (TCR) or cytokine receptors influence many aspects of $\mathrm{T}$ cell fate, and it is the ability to integrate these diverse inputs that dictates $\mathrm{T}$ cell function. It has been proposed that 'lineage specifying' is therefore a more precise term that reflects the complex roles of these transcription factors in T cell biology ${ }^{24}$. In this Review, we highlight the events that led to the discovery of T-bet and eomesodermin (EOMES) and how models of infectious disease have helped to understand the broader functions of T-bet in multiple lymphocyte populations. In addition, synthesis of the current literature highlights the idea that microbial context is a key determinant that helps to explain the threshold for when T-bet becomes essential to control certain infections. Finally, we emphasize the possible contributions of T-bet and variation in its levels of expression to the development of the effector and memory $\mathrm{T}$ cell populations that mediate long-term resistance to infection.

\section{The T-box family of transcription factors}

The discovery of the T-box family of transcription factors was based on a series of studies in mice to identify the genetic cause of a defect in tail development; a phenotype named brachyury, or $\mathrm{T}$ for tail ${ }^{25}$. Mapping of this locus identified the $T$ gene and showed that the brachyury protein contained a conserved DNA-binding motif, the T-box ${ }^{26,27}$. T-box proteins also interact with other transcription factors, such as homeodomain (encoded by Hox genes), 
GATA zinc-finger and LIM domain proteins ${ }^{28}$. The T-box genes are present in all metazoans, make up a large family and, consistent with their initial discovery, are involved in many embryonic developmental processes ${ }^{29}$. Interestingly, diversification of the TBR1 subfamily of T-box genes in ancient meta zoans coincided with the emergence of adaptive immunity and whole genome duplication events ${ }^{29,30}$. Thus, amphioxus, a common ancestor placed between vertebrates and invertebrates ${ }^{31}$, lacks an adaptive immune system but does have lymphocyte-like cells ${ }^{32}$. This marine chordate has a single gene in the Tbr1 subfamily, AmphiEomes/Tbr1/Tbx 21, which is involved in specification of the endoderm ${ }^{33}$. Lampreys share a more recent ancestor with higher vertebrates and have a variable lymphocyte receptor (VLR)-based adaptive immune system ${ }^{34}$. These jawless vertebrates have two T-box paralogues, $t b r 1 b$ and $t b \times 21$, but their function in this organism is unclear ${ }^{33,35}$. The recombination-activating gene (RAG) required for TCR-based and B cell receptor (BCR)based immunity, as well as the gene encoding IFN $\gamma(I F N G)$, first appeared in the gnathostomes, and this provided the basis for the evolution of novel mechanisms of adaptive immunity to microorganisms ${ }^{30,36}$. These jawed fish have three related genes, $T b \times 21$, Eomes and $T b r 1$, that are also present in higher vertebrates ${ }^{29}$, where Eomes functions in mesoderm development and trophoblast formation and is essential for development ${ }^{37}$. By contrast, the obser vation that $T b \times 21^{-1-}$ mice are viable suggests that T-bet has lost developmental functions associated with the other TBR1 subfamily members and may have gained immune functions distinct from those of EOMES and TBR1.

\section{T-bet and EOMES in T cell function}

The association of the $\mathrm{T}_{\mathrm{H}} 1$ cell and $\mathrm{T}_{\mathrm{H}} 2$ cell subsets with resistance to different classes of pathogens implied that there would be a molecular basis that directed differentiation of naive $\mathrm{T}$ cells into alternative fates. In the search for a $\mathrm{T}_{\mathrm{H}} 1$ cell-specific molecular switch, Glimcher and colleagues ${ }^{16,38}$ identified a T-box transcription factor expressed in $\mathrm{CD} 4{ }^{+} \mathrm{T}$ cells that is required for IFN $\gamma$ production and resistance to the intracellular parasite Leishmania major. Because of its homology with other T-box-containing genes, this novel protein was named T-box expressed in T cells (T-bet). The observation that production of IFN $\gamma$ was T-bet-independent in natural killer (NK) cells and $\mathrm{CD} 8^{+} \mathrm{T}$ cells indicated that another factor could mediate these events ${ }^{38}$. When Reiner and colleagues ${ }^{39}$ used degenerate primers to search for other T-box family members present in activated $\mathrm{CD} 8^{+} \mathrm{T}$ cells, they identified EOMES and showed that, like T-bet, it promoted IFN $\gamma$ expression. This led the authors to propose that EOMES can "complement the role of T-bet in governing cellular immunity by providing redundancy and, quite likely, cooperativity in the induction of effector genes of T cells and NK cells". It is now apparent that T-bet and EOMES have different mechanisms of induction, unique functions and possibly even antagonistic activities, perhaps mediated through competition for DNA-binding sites or transcriptional modifiers.

The molecular basis for the activating effects of T-bet and how it interacts with other transcription factors are reviewed in detail elsewhere, and molecular studies on this topic continue to provide insights into the ability of T-bet to recognize remote distal regulatory sequences and coordinate the expression of multiple genes ${ }^{40,41}$. Indeed, the effects of T-bet extend beyond trans-activation of the $I F N G$ locus, and T-bet inhibits alternative $\mathrm{CD} 4^{+} \mathrm{T}$ cell 
differentiation fates, including $\mathrm{T}_{\mathrm{H}} 2$ cell and $\mathrm{T}_{\mathrm{H}} 17$ cell development ${ }^{16,38,42}$. This can be explained by interactions between T-bet and other proteins that result in the induction or inhibition of key factors in T cell differentiation. For instance, T-bet interacts with GATA3 through a tyrosine kinase-mediated interaction, which prevents GATA3 from binding to the IL 5 promoter $^{43}$. T-bet also cooperates with runt-related transcription factor 3 (RUNX3) to activate the Ifng gene and repress the $I / 4$ gene ${ }^{44}$, while its ability to sequester RUNX1 prevents activation of Rorc, and thus limits $\mathrm{T}_{\mathrm{H}} 17$ cells $^{45}$. These examples illustrate the interactions between multiple transcription factors that enable T-bet to promote $\mathrm{T}_{\mathrm{H}} 1$ cell responses, but it is important to recognize that T-bet was originally identified as a repressor of IL-2 production ${ }^{16}$. These inhibitory properties are also apparent during the late stages of $\mathrm{T}_{\mathrm{H}} 1$ cell activation, when T-bet recruits BCL- 6 to the IFNG locus to limit IFN $\gamma$ production ${ }^{46}$. Furthermore, in differentiated $\mathrm{T}_{\mathrm{H}} 1$ cells, T-bet inhibits autocrine type I interferon signalling ${ }^{47}$ and is also associated with repression of programmed cell death 1 (PD1) expression ${ }^{48}$ but with upregulation of T cell immunoglobulin and mucin domaincontaining 3 (TIM3; also known as HAVCR2) ${ }^{49}$. Together, these studies highlight that T-bet is not simply a transactivator of the IFNG locus but can act as part of a negative-feedback loop to limit $\mathrm{T}$ cell responses (discussed below).

\section{Regulation of T-bet expression and function}

\section{Induction and activity of T-bet.}

In the initial report that identified T-bet, it was recognized that naive $\mathrm{CD} 4^{+}$and $\mathrm{CD} 8^{+} \mathrm{T}$ cells are T-bet ${ }^{-}$and that TCR activation induces T-bet expression ${ }^{16}$. Subsequent studies have highlighted that the initial events that lead to a productive $\mathrm{T}_{\mathrm{H}} 1$ cell response are characterized by two distinct waves of T-bet expression ${ }^{50,51}$. Thus, signals through the TCR and IFN $\gamma \mathrm{R}$ (via STAT1) synergize to induce early synthesis of T-bet (FIG. 1). This model is complicated by reports that, for $\mathrm{CD} 4^{+} \mathrm{T}$ cells, the initial IFN $\gamma$ response may be EOMESdependent but T-bet-independent ${ }^{52}$. Regardless, after initial $\mathrm{T}$ cell activation, local environmental signals associated with infection such as IL-12 (via STAT4 activation) induce a sustained second wave of T-bet expression that stabilizes the $\mathrm{T}_{\mathrm{H}} 1$ cell phenotype ${ }^{50,53}$ (FIG. 1). While in vitro systems illustrate the impact of IL-12 on T-bet expression, in vivo exposure to IL-12 is likely to be heterogeneous and has been linked to graded levels of T-bet expression that influence $\mathrm{T}$ cell differentiation ${ }^{54}$. The studies described above have focused on conventional $\alpha \beta \mathrm{T}$ cells, but the rules that govern T-bet activity are also relevant to other lymphocyte populations that produce IFN $\gamma$. Indeed, TCR signals lead to the induction of Tbet in $\gamma \delta \mathrm{T}_{\text {cells }}{ }^{55}$, and T-bet is also present in innate lymphoid cells (ILCs), NK cells and natural killer T (NKT) cells ${ }^{16,38,56-60}$.

The ability of IFN $\gamma$ and IL-12 to reinforce induction of T-bet is primarily linked to a commitment to a $\mathrm{T}_{\mathrm{H}} 1$ cell pheno type, but other cytokines such as type I interferons, IL-21 and IL-27 also promote T-bet expression ${ }^{61-63}$ (FIG. 1). It is unclear whether these different cytokines result in any unique effects on T-bet through the levels of T-bet that are induced, its activity or the cofactors that modulate T-bet activity. For example, it seems likely that the quantity and quality of inflammation would influence the expression of additional 
transcription factors and/or binding partners that associate with T-bet, ultimately shaping the levels and activities of T-bet in a T cell-intrinsic fashion.

The induction of T-bet represents a key early event in $\mathrm{T}$ cell activation, and it is tempting to conflate expression with transcriptional activity. However, there are numerous factors, such as metabolic status and recruitment of chromatin remodelling complexes ${ }^{64}$ or phosphorylation and ubiquitylation ${ }^{65}$, that influence T-bet activity. Indeed, in activated T cells, the subcellular localization of T-bet in the cytoplasm versus the nucleus is variable and has been linked to effector status, cell cycle and protein stability ${ }^{66-69}$. The cytoplasmic localization of T-bet may reflect a pre-formed pool present in quiescent cells that is mobilized in response to TCR signalling and which would presumably enable enhanced $\mathrm{T}_{\mathrm{H}} 1$ cell effector responses. Alternatively, in T cells, the asymmetric apportioning of the proteasome during division does result in differential degradation of T-bet, a process that would require the presence of T-bet in a cytoplasmic compartment ${ }^{67}$. Thus, the presence of cytoplasmic T-bet may provide an indicator of cells that are poised to give rise to progeny with different functions that are governed by the levels of this transcription factor.

\section{T-bet coordinates $\mathrm{T}$ cell trafficking.}

While IFN $\gamma$ production is a major characteristic of $\mathrm{T}_{\mathrm{H}} 1$ cell activity, there are other proteins, including STAT1, IL-12R $\beta 2$, CC-chemokine ligand 3 (CCL3) and CXC-chemokine receptor 3 (CXCR3), that have important roles in the immunobiology of $\mathrm{T}_{\mathrm{H}} 1$ cells, and, consonant with its role as a lineage-specifying transcription factor, T-bet can bind to the promoter region of the genes encodingthese proteins ${ }^{70-73}$. There is also evidence that T-bet may influence the $\mathrm{T}$ cell-dendritic cell (DC) interactions that are essential for $\mathrm{T}$ cell priming. For example, when $\mathrm{CD} 8^{+} \mathrm{T}$ cells are stimulated in vitro with peptide-loaded antigen-presenting cells (APCs), T-bet is required for the acquisition of an effector $\mathrm{CD} 8^{+} \mathrm{T}$ cell lymphoid structures, $\mathrm{T}$ cells phenotype (CD62 $\left.\mathrm{L}^{\mathrm{lo}} \mathrm{LY} 6 \mathrm{C}^{\mathrm{hi}}\right)$. By contrast, when $\mathrm{T}$ cells are activated through the TCR in a system that does not require DC-T cell contact, the generation of effector $\mathrm{CD} 8^{+} \mathrm{T}$ cells is $\mathrm{T}$-bet-independent ${ }^{74}$. One interpretation of these findings is that $\mathrm{T}$ bet is necessary for optimal cellular interactions during $\mathrm{T}$ cell priming, and there are several points where this may be relevant. Thus, activated $\mathrm{CD} 8^{+} \mathrm{T}$ cells produce chemokines that create their own optimal priming microenvironment through recruitment of DCs to the site of initial antigen recognition ${ }^{75}$. There is also evidence that a secondary phase $\mathrm{CD} 8^{+} \mathrm{T}$ cell priming is characterized by synaptic interactions between $\mathrm{CD}^{+} \mathrm{T}$ cells during a critical differentiation period ${ }^{76}$. Disruption of these events results in an increased ratio of memory (killer cell lectin-like receptor subfamily G member 1 (KLRG1) ${ }^{\mathrm{lo}}$ IL-7R ${ }^{\mathrm{hi}}$ ) to the IFN $\gamma$ induced chemokine CXC-chemokine ligand effector cell populations (KLRG1 ${ }^{\text {hi }} I L-7 R^{10}$ ), a phenotype that is also apparent in some infections when T-bet is absent ${ }^{54,77,78}$. The T-bet target CXCR3 also has a role in $\mathrm{CD}^{+} \mathrm{T}$ cell positioning relative to antigen and inflammatory cytokines in secondary lymphoid organs and affects the balance of effector and memory $\mathrm{T}$ cell formation ${ }^{79}$. Because the levels of T-bet are in flux during $\mathrm{T}$ cell priming, there are many points at which this variation could act in a cell-intrinsic fashion but also in trans through promotion of T cell-DC and/or T cell-T cell interactions to influence the magnitude and quality of $\mathrm{T}$ cell responses. 
After activation and differentiation in secondary lymphoid structures, $\mathrm{T}$ cells need to enter the circulation and be able to access sites of inflammation to mediate effector functions or, in the case of some forms of memory, establish tissue residency. The first report that linked T-bet to this process identified platelet selectin glycoprotein ligand 1 (PSGL1), which binds to E-selectin and L-selectin on endothelial cells, and CXCR3 as T-bet targets required on effector $\mathrm{T}$ cells for optimal trafficking to the peritoneum ${ }^{80}$ (see FIG. 2a). It is relevant to note that the activation of T-bet drives expression of enzymes, including tyrosyl protein sulfotransferase 2 (TPST2), that alter the PSGL1 post-translational modifications required for binding activity ${ }^{80}$. Indeed, PSGL1 is linked to the ability of TH1 cells to access inflamed skin $^{81,82}$ as well as to their ability to control Salmonella infection ${ }^{83}$. CXCR3, which binds to the IFN $\gamma$-induced chemokine CXC-chemokine ligand 10 (CXCL10) that is produced at sites of TH1 cell inflammation, is important for resistance to several intracellular infections that include Toxoplasma gondii and respiratory syncytial virus ${ }^{84,85}$. Furthermore, during infection with lymphocytic choriomeningitis virus (LCMV) or $T$. gondii, the absence of Tbet is associated with reduced effector T cell expression of CXCR3 as well as lower LY6C and KLRG1 expression ${ }^{54,77,86,87}$. While expression of these surface proteins is frequently used to identify T cell effector status, LY6C and the ligands for KLRG1 (namely, Ecadherin, N-cadherin and R-cadherin) have been implicated in the processes of cellular migration $^{88-90}$. This link of T-bet to lymphocyte trafficking is not restricted to effector responses: $\mathrm{T}_{\text {reg }}$ cells that express T-bet and CXCR3 can limit the inflammatory responses in the context of several intracellular infections ${ }^{91-93}$. Indeed, lineage-tracing experiments indicated that, during infection with Listeria monocytogenes, a subset of $\mathrm{T}_{\text {reg }}$ cells express T-bet stably, and this enables colocalization with effector responses at sites of IFN $\gamma$ mediated inflammation ${ }^{94}$ (see FIG. 2b). Thus, T-bet expression coordinates trafficking and behaviour of effector and regulatory $\mathrm{T}$ cells associated with $\mathrm{T}_{\mathrm{H}} 1$ cell-like responses during infection, but FOXP3 selectively opposes the development of a full $\mathrm{T}_{\mathrm{H}} 1$ cell programme. This interplay between T-bet and FOXP3 is a prominent example of how the effects of T-bet are modified in different $\mathrm{T}$ cell populations depending on the cellular environment and coexpression of additional transcription factors.

Perhaps reflecting its evolutionary link to developmental processes, several innate-like lymphocyte populations require T-bet for their maturation and activity ${ }^{58,95-98}$, as well as for their trafficking. For example, T-bet regulates sphingosine-1-phosphate receptor 5 (S1P5), which promotes lymphocyte egress from lymphoid tissues ${ }^{99}$, and both S1P5-deficient mice and T-bet-deficient mice have increased numbers of NK cells in their bone marrow 96,100 . S1P5 is also required for homeostatic NK cell positioning within the lymph node medulla, and, after immune challenge, S1P5 promotes a rapid IFN $\gamma$ response ${ }^{101}$. Nevertheless, for these innate populations, less is known about the signals that govern T-bet expression, and, while cytokines are likely candidates, the impact of other activating receptors (such as FcRs, LY49, NKp46 and NKG2D) expressed by these cells remains to be explored. 


\section{Role of T-bet in infection}

\section{T-bet-mediated resistance.}

As noted earlier, the IL-12-IFN $\gamma$ axis is an important pathway required for resistance to many viruses, bacteria and parasites, and the primary example that illustrates the importance of T-bet in $\mathrm{CD}^{+} \mathrm{T}$ cells is in mice infected with $L$. major (see TABLE 1 ). This obligate intracellular protozoan infects macrophages, and control is dependent on an IL-12-driven $\mathrm{T}_{\mathrm{H}} 1$ cell response, whereas susceptibility is associated with a $\mathrm{T}_{\mathrm{H}} 2$ cell response ${ }^{102,103}$. While C57B1/6 mice normally control this infection, the absence of T-bet in this mouse strain leads to reduced IFN $\gamma$, increased IL-4 and IL-5 and disease progression ${ }^{38}$. In other words, the loss of T-bet does not prevent the emergence of an L. major-specific CD4 ${ }^{+} \mathrm{T}$ cell response, but a non-protective $\mathrm{T}_{\mathrm{H}} 2$ cell response dominates. This study suggested that $\mathrm{T}$-bet overrides a default pathway that leads to $T_{H} 2$ cells in order to induce $T_{H} 1$ cells and foreshadowed the complex relationship between T-bet and GATA3. However, whereas IFN $\gamma$ is important for resistance to Mycobacterium tuberculosis or Salmonella enterica subsp. enterica serovar Typhimurium, $\mathrm{T}_{\mathrm{H}} 2$ cells do not have a prominent role in disease susceptibility ${ }^{104,105}$. $T b \times 21^{-1-}$ mice challenged with either of these pathogens have reduced $\mathrm{CD}^{+} \mathrm{T}$ cell production of IFN $\gamma$ and are more susceptible to infection, but this is not accompanied by the emergence of $\mathrm{T}_{\mathrm{H}} 2$ cell-type activities ${ }^{106,107}$. Thus, in these infectious systems, the ability of T-bet to block $\mathrm{T}_{\mathrm{H}} 2$ cell development appears irrelevant, and its protective activities track most closely with the induction of IFN $\gamma$-producing $\mathrm{CD} 4^{+} \mathrm{T}$ cells.

\section{T-bet-independent resistance.}

There has been a tendency to describe antimicrobial responses dominated by the production of IFN $\gamma$ as $\mathrm{T}_{\mathrm{H}} 1$ cell-like regardless of the cellular source of this cytokine (for example, IFN $\gamma$ can be produced by ILCs, $\gamma \delta \mathrm{T}$ cells and $\mathrm{CD} 4^{+}$and $\mathrm{CD} 8^{+} \mathrm{T}$ cells during infection). One unintended consequence of this classification is that it implies that the cellular source of IFN $\gamma$ is not critical for pathogen control, but this becomes an important consideration in systems in which the loss of T-bet is not synonymous with increased susceptibility to infection (see TABLE 1). The role of T-bet-independent IFN $\gamma$ is most apparent in infections that are not dominated by $\mathrm{CD} 4^{+} \mathrm{T}$ cells and where other lymphocytes are major sources of IFN $\gamma$. Thus, murine cytomegalovirus (MCMV) infection induces potent NK cell production of IFN $\gamma$ that mediates viral control, and while there are reduced numbers of NK cells in $T b \times 21^{-1-}$ mice, those that are present are sufficient to limit viral replication ${ }^{96}$. Similarly, $T b \times 21^{-1-}$ mice infected with $L$. monocytogenes have reduced $\mathrm{CD}^{+} \mathrm{T}$ cell production of IFN $\gamma$, but the $\mathrm{NK}$ and $\mathrm{CD} 8^{+} \mathrm{T}$ cell responses appear intact, and these mice control bacterial replication ${ }^{108}$. Similarly, the Armstrong strain of LCMV induces an acute viraemia that is cleared via CD8 ${ }^{+} \mathrm{T}$ cell-dependent and IFN $\gamma \mathrm{R}$-dependent mechanisms ${ }^{109}$. When $T b \times 21^{-1-}$ mice or those in which T cells lack EOMES are challenged with this strain of LCMV, the $\mathrm{CD} 8^{+} \mathrm{T}$ cells produce normal levels of IFN $\gamma$, and there is no obvious alteration in viral control or disease severity ${ }^{110}$. However, when mice that lacked both T-bet and EOMES in their $\mathrm{T}$ cells received the same challenge, there was a major defect in IFN $\gamma$ production, reduced cytolytic activity and failure to control viral replication ${ }^{110}$. This phenotype provided evidence for the original prediction of functional redundancy and/or cooperativity between T-bet and EOMES. Unexpectedly at the time, these double knockouts had increased IL-17 
production associated with a pathological neutrophil response ${ }^{110}$, consistent with a role for T-bet in the suppression of Rorc and $\mathrm{T}_{\mathrm{H}} 17$ cell responses ${ }^{42,45}$. By contrast, LCMV clone 13 causes a chronic infection with a low viral load, but $T b \times 21^{-1-}$ mice infected with this strain have reduced numbers of antigen-specific $\mathrm{CD} 8^{+} \mathrm{T}$ cells and are unable to control viral replication ${ }^{48}$. A recent study has shown that the strength of TCR signalling can regulate the relative expression of T-bet and EOMES after infection with LCMV clone 13, and manipulation to increase the ratio of T-bet to EOMES within the $\mathrm{CD}^{+} \mathrm{T}$ cells results in better viral control ${ }^{111}$. The variable outcomes associated with different strains of LCMV highlight that the requirement for T-bet (and/or EOMES) to coordinate protective immunity can be profoundly influenced by microbial context.

\section{Microbial context matters.}

For some eukaryotic pathogens, such as T. gondii, Plasmodium spp. and Trypanosoma cruzi, their complex life cycles and evasion strategies contribute to chronicity. This in turn requires full integration of cellular and humoral responses for parasite control, and the loss of T-bet can impact on many different facets of protective immunity. Thus, $T b \times 21^{-1-}$ mice challenged with $T$. gondii have reduced $\mathrm{CD} 4^{+} \mathrm{T}$ cell production of IFN $\gamma$, but NK cell production of IFN $\gamma$ enables parasite control at the initial site of infection ${ }^{70,77}$. However, in the absence of T-bet, the $T$. gondii-specific $\mathrm{CD} 4^{+}$and $\mathrm{CD} 8^{+} \mathrm{T}$ cells express reduced levels of the integrin CD11a as well as CXCR3 (REF. ${ }^{77}$ ). Both of these molecules regulate different aspects of $\mathrm{T}$ cell migration into inflammatory environments ${ }^{85,112,113}$. Consequently, as T. gondii disseminates into secondary sites of infection in the $\mathrm{Tb} \times 21^{-1-}$ mice, there is a failure to recruit parasite-specific $\mathrm{T}$ cells into the affected tissues to limit parasite replication ${ }^{77}$. A related phenotype is observed in a mouse model of cerebral malaria in which the recruitment of $\mathrm{CD} 8^{+} \mathrm{T}$ cells to the central nervous system causes local damage, but $\mathrm{Tb} \times 21^{-1-}$ mice have reduced $\mathrm{T}$ cell trafficking to the brain and less neuropathology and are resistant to disease ${ }^{114}$. These two reports highlight that effector T cell trafficking should be considered a major function of T-bet required for local tissue responses during infection (see FIG. 2). For T. cruzi, the role of T-bet appears more complex, as it is required for expansion of parasitespecific $\mathrm{CD} 8^{+} \mathrm{T}$ cell populations but not for the ability of $\mathrm{CD} 4^{+} \mathrm{T}$ cells to produce IFN $\gamma^{115,116}$. Surprisingly, despite apparently normal circulating levels of IFN $\gamma$, the $\operatorname{Tb} \times 21^{-1-}$ mice still succumb to acute infection associated with the appearance of a polyfunctional population of $\mathrm{CD}^{+} \mathrm{T}$ cells that co-produce IFN $\gamma$ and IL-17 (REFS ${ }^{115,116}$ ). Although IL-17 plays a protective role during infection with T. cruzi ${ }^{117,118}$, it remains unclear whether the elevated IL-17 observed in the $T b \times 21^{-1-}$ mice in this setting contributes to the development of immune pathology. This inverse relationship between T-bet and IL-17 is observed in many systems but can manifest in different ways. In a model of post-influenza bacterial superinfection, the challenge of $T b \times 21^{-1-}$ mice with influenza results in increased IL-17 production that protects against subsequent challenge with Streptococcus pneumoniae ${ }^{119}$. Furthermore, while IL-17 signalling is protective after infection with the live vaccine strain of Francisella tularensis ${ }^{120}$, the susceptibility of $T b \times 21^{-1-}$ mice to infection with this pathogen is associated with increased IL-17 production ${ }^{121}$. Similarly, the observation that RAG mice that lack T-bet can spontaneously develop bacteria-driven colitis provided critical evidence that T-bet functions in innate cells to limit the emergence of colitogenic bacterial species ${ }^{122}$. Further studies on these phenomena revealed that, in the 
absence of T-bet, ILCs fail to produce IFN $\gamma$ but instead produce IL-17 that contributes to the development of mucosal inflammation ${ }^{60}$.

These results using $T b \times 21^{-1-}$ mice illustrate the range of phenotypes that occur with different viral, bacterial and parasitic organisms and even within strains of the same pathogen. Perhaps one of the main lessons from the opportunity to consider this literature is that the absence of T-bet does not inevitably lead to increased susceptibility to intracellular pathogens. Rather, the type and magnitude of the immune response required for resistance may determine the threshold for when T-bet becomes essential (see FIG. 3). For example, the role of T-bet in host protection is less critical in settings where NK cells and $\mathrm{CD} 8^{+} \mathrm{T}$ cells are major sources of IFN $\gamma$, as these are cells in which EOMES can mediate Tbetindependent pathways to IFN $\gamma$. When looking at the variable phenotypes shown in TABLE 1, T-bet is essential for the development of $\mathrm{T}_{\mathrm{H}} 1$ cells and for resistance to infections that are associated with the lysosomal system. Thus, for L. major, M. tuberculosis, S. Typhimurium and Francisella spp., their association with the phagolysosomal system means that their antigens should be readily accessible to the MHC class II antigen-processing machinery, enabling $\mathrm{CD} 4^{+} \mathrm{T}$ cells to recognize infected cells. By contrast, T-bet does not appear so critical to control T. cruzi and Listeria spp., which reside in the cytosol of infected cells. Consequently, the transporter associated with antigen processing (TAP)-dependent MHC class I antigen-processing pathway would have most ready access to pathogen-derived antigens present in non-lysosomal compartments. Perhaps the most complex phenotype relates to T. gondii, which exists within a non-fusogenic parasitophorous vacuole of haematopoietic and non-haematopoietic cells. For this obligate intracellular organism, the pathways that enable infected cells to present antigen are less obvious. Thus, despite the fact that $\mathrm{CD} 4^{+} \mathrm{T}$ cell responses are associated with each of these infections, NK cells or $\mathrm{CD} 8^{+} \mathrm{T}$ cells appear to be sufficient sources of IFN $\gamma$ and provide a T-bet-independent pathway that enables the development of pathogen-specific T cells. Paradoxically, T-bet-haplosufficient mice (with an intermediate level of T-bet expression) challenged with $M$. tuberculosis have an improved ability to control bacterial replication compared with T-bet-sufficient mice ${ }^{123}$. Perhaps this observation is related to the finding that T-bet promotes the differentiation of a non-protective $\mathrm{CX}_{3} \mathrm{C}$-chemokine receptor $1\left(\mathrm{CX}_{3} \mathrm{CR} 1\right)^{+} \mathrm{KLRG} 1^{+}$population of intravascular $\mathrm{CD}^{+}{ }^{+} \mathrm{T}$ cells after $M$. tuberculosis infection ${ }^{124}$. These observations are complimented by experiments showing that ectopic expression of high levels of T-bet compromises the immune response to the neurotropic Theiler's encephalomyelitis virus ${ }^{125}$. The basis for these phenotypes is unclear but may be related to the repressive effects of T-bet (discussed earlier) that are part of a feedback loop that dampens $\mathrm{T}$ cell responses.

\section{T-bet and humoral responses}

While the sections above have focused on the role of T-bet in cell-mediated immunity, $\mathrm{T}_{\mathrm{H}} 1$ cells and their production of IFN $\gamma$ are also linked to the production of IgG isotypes associated with antibody-dependent cell-mediated cytotoxicity, and early reports indicated that this arm of the immune response was T-betdependent ${ }^{38}$. For example, during infection with LCMV, downstream of STAT4 phosphorylation, T-bet is co-expressed with BCL-6 in $\mathrm{T}_{\mathrm{FH}}$ cells and coordinates IFN $\gamma$ production that promotes the germinal centre response ${ }^{126}$. Recent studies in a model of vaccination also established that T-bet is required for the 
development of $\mathrm{T}_{\mathrm{FH}}$ cells that produce IFN $\gamma$ but that conditional deletion of T-bet after the differentiation of these cells did not affect their ability to make IFN $\gamma^{127}$. However, the role of T-bet in humoral immunity is not restricted to T cells, and in lupus-prone mice (in which self nucleic acids may act as an adjuvant), B cell expression of T-bet was required for maximal IgG2a levels, although there was a significant T-bet-independent component ${ }^{128}$. Similarly, other studies found that the ability of T cells to express CD40L and thereby engage CD40 on B cells required for class switching was independent of T-bet but that T cell-independent $\mathrm{B}$ cell responses to lipopolysaccharide were T-bet-dependent ${ }^{129}$. These latter observations are consistent with reports that T-bet expression is induced in B cells via BCR signalling that synergizes with IFN $\gamma^{130}$ or alternatively after ligation of Toll-like receptor 9 (TLR9) and subsequent MYD88 signalling ${ }^{131,132}$. Perhaps similar to the ability of $\mathrm{T}_{\mathrm{H}} 1$ cells and $\mathrm{T}_{\mathrm{H}} 2$ cells to cross-regulate, there are mechanisms to repress T-bet expression in B cells, and treatment with IL-4 antagonizes the induction of T-bet ${ }^{133}$. These parallels extend to the molecular level, and the expression of T-bet target genes is diminished in germinal centre B cells that express high levels of BCL-6, likely through the direct interaction of these transcription factors ${ }^{134}$. Additionally, the expression of B lymphocyteinduced maturation protein 1 (BLIMP1) in plasma cells appears to antagonize T-bet activity $^{134}$, as does the expression of the transcription factor MYB in germinal centre B cells $^{135}$.

Subsequent studies have highlighted the role of T-bet in IFN $\gamma$-mediated class switching. In a model that used alum as the adjuvant, T-bet was dispensable for IFN $\gamma$-mediated class-switch recombination to the $\mathrm{IgG} 2 \mathrm{~b}$ isotype and for the inhibition of the IgG1 isotype, but T-bet did have a role in the generation of IFN $\gamma$-mediated IgG2a responses ${ }^{136}$. Similarly, in mice immunized with the haptenated antigen NP-KLH combined with a lipid A adjuvant, T-bet is not required to generate antibody-secreting cells but is required for class-switch recombination to the $\operatorname{IgG} 2 \mathrm{a}$ and $\operatorname{IgG} 2 \mathrm{c}$ isotypes and for the survival of $\operatorname{IgG} 2 \mathrm{a}^{+}$memory B cells ${ }^{134}$. Among memory B cells, T-bet is expressed in age-associated B cells that appear during humoral autoimmune disease and in the atypical memory $\mathrm{B}$ cells that arise following chronic infections ${ }^{137,138}$. Indeed, in a murine model, B cell-intrinsic T-bet expression is required to control $\mathrm{LCMV}^{139}$, and during acute HIV or following vaccination for yellow fever or vaccinia, viral titres correlate with the maintenance of T-bet expression among B cells $^{140}$. Thus, a picture has emerged in which T-bet ${ }^{+} \mathrm{B}$ cells are not prominent in the commonly used adjuvant-hapten carrier systems but are most apparent in settings where nucleic acids or microbial products act as adjuvants that drive IFN $\gamma$ production and when these adjuvants can act directly on B cells ${ }^{139-141}$.

\section{T-bet in chronic infection and memory}

The availability of $T b \times 21^{-1-}$ mice facilitated studies to evaluate how the complete absence of T-bet influences $\mathrm{T}$ cell and B cell responses during infection. However, the expression of Tbet and EOMES in lymphocyte populations is not digital, and their maintenance in pathogen-specific $\mathrm{T}$ cells during persistent infection implies roles that extend beyond the initial development of effector responses. It has been a challenge to distinguish how the activity of T-bet during $\mathrm{T}$ cell priming might affect the quality of long-lived $\mathrm{T}$ cell populations versus a role for T-bet in the maintenance of these cells or during a secondary 
immune response. Nevertheless, in clinical and experimental infections, variations in the levels of these transcription factors appear biologically relevant. For example, in patients infected with hepatitis $\mathrm{B}$ or hepatitis $\mathrm{C}$, the presence of T-bet ${ }^{\text {hi }}$ virus-specific $\mathrm{CD} 8^{+} \mathrm{T}$ cells is associated with spontaneous resolution, whereas lower levels of T-bet are characteristic of progressive disease ${ }^{142}$. Similarly, HIV-specific $\mathrm{CD} 8^{+} \mathrm{T}$ cells from elite controllers express higher levels of T-bet than those from chronically infected progressors or individuals treated with highly active antiretroviral therapy ${ }^{143}$, and decreased T-bet correlated with loss of effector function ${ }^{144}$. The observation that T-bet and EOMES are reciprocally expressed by HIV-specific CD8 ${ }^{+} \mathrm{T}$ cells and that EOMES is associated with expression of the inhibitory receptors PD1 and CD160 (REF. ${ }^{145}$ ) may help to explain the decreased functionality of $\mathrm{CD} 8^{+} \mathrm{T}$ cells that characterizes HIV progression. The ability to detect variation in T-bet and EOMES expression combined with the application of longitudinal immune profiling to clinical cohorts may help to develop algorithms in which the levels of these transcription factors can be used to predict disease progression and/or responsiveness to immune therapies.

The expression of variable levels of T-bet by pathogen-specific $\mathrm{T}$ cells has been noted in many infections, and these have frequently been associated with different stages of $\mathrm{T}$ cell activation and effector function. This has perhaps been best studied using LCMV infection, and in this model, short-lived effector T cells (SLECs) express high levels of T-bet, whereas memory precursor effector cells express lower levels of T-bet ${ }^{54,78,86,87,146}$. These data suggest one model of effector differentiation common to $\mathrm{CD} 4^{+}$and $\mathrm{CD} 8^{+} \mathrm{T}$ cells wherein less differentiated T-bet ${ }^{\text {int }}$ effector cells can form and persist or further differentiate into terminal T-bet ${ }^{\mathrm{hi}}$ effector cells with robust effector function but reduced memory cell potential $^{146}$ (see FIG. 4). By contrast, in T-betdeficient mice infected with LCMVArmstrong, there is a decrease in effector $\mathrm{T}$ cells but enhanced generation of $\mathrm{CD} 27^{\mathrm{hi}}{ }_{\mathrm{KLRG}} 1^{\mathrm{lo}}$ central memory $\mathrm{CD} 8^{+} \mathrm{T}$ cells that confer better protection to a secondary challenge ${ }^{78}$. This unexpected observation suggests that T-bet inhibits memory formation and is consistent with the idea that the magnitude of the primary effector response is inversely correlated with the generation of memory responses ${ }^{147,148}$. The complex role of T-bet in effector and memory fate decisions is illustrated by the apparent role reversal of T-bet and EOMES in the maintenance of self-renewing $\mathrm{CD} 8^{+} \mathrm{T}$ cells after chronic LCMV challenge; T-bet ${ }^{\text {hi }}$ precursors are required to generate EOMES ${ }^{\text {hi }}$ terminally differentiated effectors, which display higher expression of inhibitory receptors ${ }^{149}$. This contradiction has never been fully resolved, but the report that similar EOMES ${ }^{\text {hi }} \mathrm{T}-$ bet $^{\text {lo }} \mathrm{CD}^{+} \mathrm{T}$ cells that express inhibitory receptors at a high level are found in the tumour microenvironment ${ }^{150}$ suggests that this transcriptional state is substantially influenced by chronic antigen load. By contrast, as previously mentioned, altering the strength of TCR signalling can increase the proportion of T-bet relative to EOMES, which leads to clearance of this chronic infection, suggesting that the transcriptional state influences the ability to respond to chronic infection ${ }^{111}$.

The infectious examples described above indicate that the impact of changes in the relative levels of these transcription factors is context-dependent and that the specific conclusions from these studies reflect the experimental questions being addressed (that is, mechanisms of exhaustion versus impact on resident tissue memory). For example, in a model of epicutaneous challenge with herpes simplex virus, development of $\mathrm{CD}^{+} \mathrm{CD} 103^{+}$tissue- 
resident memory $\mathrm{T}\left(\mathrm{T}_{\mathrm{RM}}\right)$ cells in the skin requires downregulation of EOMES, but low levels of T-bet are necessary to maintain expression of CD122, the $\beta$-chain of the IL-15R, which promotes the survival of $\mathrm{T}_{\mathrm{RM}}$ cells ${ }^{151}$. However, in the context of a molecular adjuvant designed to directly engage CD40 and TLR2 and/or TLR3, the loss of either T-bet or EOMES (likely downstream of IL-15 and IL-27) compromises clonal expansion ${ }^{152}$. This is a finding that runs counter to the majority of the infectious disease literature and highlights that the levels of inflammation associated with infection may override the need for T-bet and EOMES, whereas during subunit vaccination, their critical $\mathrm{c}$ ontributions are more apparent.

Another area that has seen advances relates to reports that link T-bet and EOMES expression with different stages of development of $\mathrm{T}$ cell responses: early effectors, proliferative intermediates and various forms of memory (see FIG. 4). This is a topic that is complicated by the variation in the markers used to identify different subsets or developmental stages of $\mathrm{T}$ cell activation. As previously noted ${ }^{153}$, "single, or even a handful, of markers is unlikely to reliably predict either the developmental or protective potential of "subsets" that transcends single experimental systems". In other words, the combination of CD44 and CD62L to distinguish effector and memory populations has been replaced by more complex combinations of surface molecules (adhesion molecules and cytokine and chemokine receptors) and transcription factors that can differ between infectious agents. This is illustrated by the studies with vaccinia or Listeria spp. discussed above, the infections of which induce a population of KLRG $1^{\mathrm{hi}}{ }^{\mathrm{T}}$-bet ${ }^{\mathrm{hi}} \mathrm{EOMES}^{\mathrm{lo}} \mathrm{CD} 8^{+} \mathrm{T}$ cells (typically an effector phenotype during LCMV infection) that persists in the memory phase and, despite low proliferative potential, provides optimal protection against re-challenge ${ }^{154}$. The integration of an additional persistent infectious disease, such as infection with MCMV, suggests a model in which memory cells that express CD27, CD127 (IL-7RA) and CD122 (IL-15R 3 ) at a high level are derived early during infection, whereas SLECs are continuously generated from this population ${ }^{155}$.

A similar theme has emerged during infection with $T$. gondii, in which persistent antigen induces a CD8 ${ }^{+} \mathrm{T}$ cell memory-effector hybrid intermediate that expresses T-bet, CXCR3 and KLRG1 and gives rise to CXCR3-negative SLECs ${ }^{156}$. Certainly, in this setting, T-bet is required for optimal expression of $\mathrm{CXCR} 3$ and $\mathrm{T}$ cell migration into affected tissues ${ }^{77}$. Additionally, Knolle and colleagues ${ }^{157}$ have used expression of the $\mathrm{CX}_{3} \mathrm{CL} 1$ (also known as fractalkine) receptor $\mathrm{CX}_{3} \mathrm{CR} 1$ to distinguish cytotoxic and proliferative capacity among human and mouse memory $\mathrm{CD}^{+} \mathrm{T}$ cells. In murine models with Listeria spp. and LCMV infections, after the initial $\mathrm{T}$ cell expansion, there was an abrupt transition in which a significant percentage of these cells started to express $\mathrm{CX}_{3} \mathrm{CR} 1$. Subsequent studies demonstrated that, in response to $\mathrm{LCMV}, \mathrm{CD}^{+}$central memory $\mathrm{T}$ cells that express low levels of $\mathrm{CX}_{3} \mathrm{CR} 1$ can give rise to effector memory cell populations that are $\mathrm{CX}_{3} \mathrm{CR} 1^{\text {int }}$ or $\mathrm{CX}_{3} \mathrm{CR} 1^{\text {hi }}$. Importantly, while T-bet was expressed in each population, the $\mathrm{CX}_{3} \mathrm{CR} 1^{\mathrm{hi}}$ cells were T-bet-dependent ${ }^{158}$. These results are consistent with the ability of T-bet to bind to the $\mathrm{CX}_{3} \mathrm{CR} 1$ gene locus ${ }^{73}$, but the impact of $\mathrm{CX}_{3} \mathrm{CR} 1$ expression on the function of these cells remains unclear. Interestingly, lineage tracing indicates that KLRG1+T-bet ${ }^{\text {hi }}$ cells that receive intermediate amounts of inflammatory signals can give rise to all memory $\mathrm{T}$ cell lineages, including $\mathrm{CX}_{3} \mathrm{CR} 1^{\text {int }}$ peripheral memory cells and $\mathrm{T}_{\mathrm{RM}}$ cells, and that the relative 
levels of T-bet vary between these different subsets ${ }^{159}$. Whether these data sets are indicative of a high level of phenotypic plasticity that underlies the ability to generate diverse types of effector and memory populations or that variations in the levels of T-bet i nfluence these events remains to be addressed.

\section{Future directions}

This Review has emphasized how mouse models of infection have led to a better appreciation of the broad effects of T-bet and EOMES on lymphocyte biology. A major challenge exists to determine which of these features are shared with humans or whether these transcription factors have distinct functions associated with human diseases. There are numerous examples that illustrate changes in T-bet expression during human infections or lymphoproliferative disorders that correlate with disease progression or resolution ${ }^{142-144,160-164}$. There are also 40 known polymorphisms of the human TBX21 gene, one of which has been associated with susceptibility to type 1 diabetes ${ }^{165}$, while another is associated with herpes simplex virus 2 incidence ${ }^{166}$. How the other 38 known polymorphisms impact human immune responses to infectious disease is unknown.

Since the original paradigm in which T-bet was considered the master regulator of $\mathrm{T}_{\mathrm{H}} 1$ cell responses, we have moved through the model of functional redundancy between T-bet and EOMES and to a situation in which the precise role of these factors in $\mathrm{T}$ cell fate determination is context-dependent and guided by the inflammatory environment and duration of antigen encounter. Thus, while both T-bet and EOMES can promote IFN $\gamma$ production, they have different effects on $\mathrm{T}$ cell phenotypes and functions, as highlighted by the differential functions of T-bet and EOMES during acute and chronic viral infections, and there is evidence that the relative ratio of T-bet to EOMES matters. It does seem intuitive that T-bet has core functions common to early-stage or late-stage effectors or in different memory populations, but changes in the chromatin landscape or the presence of other transcriptions factors (such as FOXP3, BLIMP1, BCL-6 and GATA3) that are associated with the diversification of lymphocyte responses would result in the acquisition or loss of regulatory functions. The development of genetic approaches to conditionally delete T-bet ${ }^{127}$ will provide an important tool to understand the functions of T-bet at later stages of $\mathrm{T}$ cell (and B cell) development and to test whether T-bet is required for quiescent memory cells to rapidly (re)engage effector activities or give rise to progeny that have the ability to synthesize IFN $\gamma$ immediately (see FIG. 4).

There have been many studies that have examined the role of T-bet during infection, but there is a paucity of reports that directly assess the contribution of EOMES to the immune response to diverse bacterial and parasitic pathogens. Given the context-dependent function of these factors, as outlined above, a survey of the function of EOMES across different infections may help to understand how and where (or whether) EOMES has a dominant role in the control of a particular type of infection or in immune homeostasis. A good example is the increasingly appreciated role for T-bet in B cells, which lends credence to a possible role for EOMES in these lymphocytes. This resurgence in interest does highlight that, even though a cell-intrinsic role for T-bet in B cell function was described early, the focus on $\mathrm{T}$ cells perhaps limited our perspective of T-bet as a lineage-defining factor when in fact it is 
broadly expressed in immune cell populations. We now know that there are multiple pathways mediated by diverse stimuli (for example, cytokines, TLR signals and TCR and BCR signalling) that promote NK cell, T cell and B cell expression of T-bet and that this varies enormously among infections. Perhaps the emergence of T-bet contemporaneously with the genes encoding RAG and IFN $\gamma$ and its ability to coordinate innate and adaptive, cellular and humoral responses are consistent with its function as a central regulator of an evolutionarily conserved response that integrates antigenic and environmental cues to facilitate host protection against a broad s pectrum of pathogens.

\section{Acknowledgements}

The authors thank S. Reiner for ongoing discussions. Funding support was provided by the National Institutes of Health (NIH) to all authors and the Commonwealth of Pennsylvania to C.A.H.

\section{References}

1. Miller JF \& Mitchell GF The thymus and the precursors of antigen reactive cells. Nature 216, 659663 (1967). [PubMed: 6082462]

2. Miller JF Discovering the origins of immunological competence. Annu. Rev. Immunol 17, 1-17 (1999). [PubMed: 10358751]

3. Golstein P, Wigzell H, Blomgren H \& Svedmyr EA Cells mediating specific in vitro cytotoxicity. II. Probable autonomy of thymus-processed lymphocytes T cells) for the killing of allogeneic target cells. J. Exp. Med 135, 890-906 (1972). [PubMed: 5018054]

4. Cantor H \& Boyse EA Functional subclasses of T-lymphocytes bearing different Ly antigens. I. The generation of functionally distinct $\mathrm{T}$ cell subclasses is a differentiative process independent of antigen. J. Exp. Med 141, 1376-1389 (1975). [PubMed: 1092798]

5. Mosmann TR, Cherwinski H, Bond MW, Giedlin MA \& Coffman RL Two types of murine helper T cell clone. I. Definition according to profiles of lymphokine activities and secreted proteins. J. Immunol 136, 2348-2357 (1986). [PubMed: 2419430]

6. Mosmann TR \& Coffman RL TH1 and TH2 cells: different patterns of lymphokine secretion lead to different functional properties. Annu. Rev. Immunol 7, 145-173 (1989). [PubMed: 2523712]

7. Vignali DA, Collison LW \& Workman CJ How regulatory T cells work. Nat. Rev. Immunol 8, $523-$ 532 (2008). [PubMed: 18566595]

8. Stockinger B \& Omenetti S The dichotomous nature of T helper 17 cells. Nat. Rev. Immunol 17, 535-544 (2017). [PubMed: 28555673]

9. Vinuesa CG, Tangye SG, Moser B \& Mackay CR Follicular B helper T cells in antibody responses and autoimmunity. Nat. Rev. Immunol 5, 853-865 (2005). [PubMed: 16261173]

10. Fletcher JM, Lalor SJ, Sweeney CM, Tubridy N \& Mills KH T cells in multiple sclerosis and experimental autoimmune encephalomyelitis. Clin. Exp. Immunol 162, 1-11 (2010). [PubMed: 20682002]

11. Umetsu DT, McIntire JJ, Akbari O, Macaubas C \& DeKruyff RH Asthma: an epidemic of dysregulated immunity. Nat. Immunol 3, 715-720 (2002). [PubMed: 12145657]

12. Xu XR, Liu CQ, Feng BS \& Liu ZJ Dysregulation of mucosal immune response in pathogenesis of inflammatory bowel disease. World J. Gastroenterol 20, 3255-3264 (2014). [PubMed: 24695798]

13. McInnes IB \& Schett G Cytokines in the pathogenesis of rheumatoid arthritis. Nat. Rev. Immunol 7, 429-442 (2007). [PubMed: 17525752]

14. Kim JI, Ho IC, Grusby MJ \& Glimcher LH The transcription factor c-Maf controls the production of interleukin-4 but not other Th2 cytokines. Immunity 10, 745-751 (1999). [PubMed: 10403649]

15. Zheng W \& Flavell RA The transcription factor GATA-3 is necessary and sufficient for Th2 cytokine gene expression in CD4 T cells. Cell 89, 587-596 (1997). [PubMed: 9160750]

16. Szabo SJ et al. A novel transcription factor, T-bet, directs Th1 lineage commitment. Cell 100, 655669 (2000). [PubMed: 10761931] 
17. Hori S, Nomura T \& Sakaguchi S Control of regulatory T cell development by the transcription factor Foxp3. Science 299, 1057-1061 (2003). [PubMed: 12522256]

18. Fontenot JD, Gavin MA \& Rudensky AY Foxp3 programs the development and function of CD4+CD25+regulatory T cells. Nat. Immunol 4, 330-336 (2003). [PubMed: 12612578]

19. Ivanov II et al. The orphan nuclear receptor RORgammat directs the differentiation program of proinflammatory IL-17 + T helper cells. Cell 126, 1121-1133 (2006). [PubMed: 16990136]

20. Yu D et al. The transcriptional repressor Bcl-6 directs T follicular helper cell lineage commitment. Immunity 31, 457-468 (2009). [PubMed: 19631565]

21. Nurieva RI et al. Bcl6 mediates the development of T follicular helper cells. Science 325, 10011005 (2009). [PubMed: 19628815]

22. Johnston RJ et al. Bcl6 and Blimp-1 are reciprocal and antagonistic regulators of $\mathrm{T}$ follicular helper cell differentiation. Science 325, 1006-1010 (2009). [PubMed: 19608860]

23. Chan SS \& Kyba M What is a master regulator? J. Stem Cell. Res. Ther 3, 114 (2013). [PubMed: 23885309]

24. Oestreich KJ \& Weinmann AS Master regulators or lineage-specifying? Changing views on CD4 T cell transcription factors. Nat. Rev. Immunol 12, 799-804 (2012). [PubMed: 23059426]

25. Wattler S, Russ A, Evans M \& Nehls M A combined analysis of genomic and primary protein structure defines the phylogenetic relationship of new members if the T-box family. Genomics 48, 24-33 (1998). [PubMed: 9503012]

26. Bollag RJ et al. An ancient family of embryonically expressed mouse genes sharing a conserved protein motif with the T locus. Nat. Genet 7, 383-389 (1994). [PubMed: 7920656]

27. Herrmann BG, Labeit S, Poustka A, King TR \& Lehrach H Cloning of the $\mathrm{T}$ gene required in mesoderm formation in the mouse. Nature 343, 617-622 (1990). [PubMed: 2154694]

28. Naiche LA, Harrelson Z, Kelly RG \& Papaioannou VE T-box genes in vertebrate development. Annu. Rev. Genet 39, 219-239 (2005). [PubMed: 16285859]

29. Papaioannou VE The T-box gene family: emerging roles in development, stem cells and cancer. Development 141, 3819-3833 (2014). [PubMed: 25294936]

30. Flajnik MF \& Kasahara M Origin and evolution of the adaptive immune system: genetic events and selective pressures. Nat. Rev. Genet 11, 47-59 (2010). [PubMed: 19997068]

31. Bertrand S \& Escriva H Evolutionary crossroads in developmental biology: amphioxus. Development 138, 4819-4830 (2011). [PubMed: 22028023]

32. Huang $\mathrm{G}$ et al. The identification of lymphocyte-like cells and lymphoid-related genes in amphioxus indicates the twilight for the emergence of adaptive immune system. PLOS ONE 2, e206 (2007). [PubMed: 17299586]

33. Horton AC \& Gibson-Brown JJ Evolution of developmental functions by the Eomesodermin, Tbrain-1, Tbx21 subfamily of T-box genes: insights from amphioxus. J. Exp. Zool 294, 112-121 (2002). [PubMed: 12210112]

34. Boehm T et al. VLR-based adaptive immunity. Annu. Rev. Immunol 30, 203-220 (2012). [PubMed: 22224775]

35. Kang J \& Malhotra N Transcription factor networks directing the development, function, and evolution of innate lymphoid effectors. Annu. Rev. Immunol 33, 505-538 (2015). [PubMed: 25650177]

36. Secombes CJ \& Zou J Evolution of interferons and interferon receptors. Front. Immunol 8, 209 (2017). [PubMed: 28303139]

37. Russ AP et al. Eomesodermin is required for mouse trophoblast development and mesoderm formation. Nature 404, 95-99 (2000). [PubMed: 10716450]

38. Szabo SJ et al. Distinct effects of T-bet in TH1 lineage commitment and IFN-gamma production in CD4 and CD8 T cells. Science 295, 338-342 (2002). [PubMed: 11786644]

39. Pearce EL et al. Control of effector $\mathrm{CD} 8_{+} \mathrm{T}$ cell function by the transcription factor eomesodermin. Science 302, 1041-1043 (2003). [PubMed: 14605368]

40. Kallies A \& Good-Jacobson KL Transcription factor T-bet orchestrates lineage development and function in the immune system. Trends Immunol. 38, 287-297 (2017). [PubMed: 28279590] 
41. Zhang J et al. T-bet and Eomes govern differentiation and function of mouse and human NK cells and ILC1. Eur. J. Immunol 48, 738-750 (2018). [PubMed: 29424438]

42. Mathur AN et al. T-bet is a critical determinant in the instability of the IL-17-secreting T-helper phenotype. Blood 108, 1595-1601 (2006). [PubMed: 16670261]

43. Hwang ES, Szabo SJ, Schwartzberg PL \& Glimcher LH T helper cell fate specified by kinasemediated interaction of T-bet with GATA-3. Science 307, 430-433 (2005). [PubMed: 15662016]

44. Djuretic IM et al. Transcription factors T-bet and Runx3 cooperate to activate Ifng and silence Il4 in T helper type 1 cells. Nat. Immunol 8, 145-153 (2007). [PubMed: 17195845]

45. Lazarevic $\mathrm{V}$ et al. T-bet represses $\mathrm{T}(\mathrm{H}) 17$ differentiation by preventing Runx1-mediated activation of the gene encoding RORgammat. Nat. Immunol 12, 96-104 (2011). [PubMed: 21151104]

46. Oestreich KJ, Huang AC \& Weinmann AS The lineage-defining factors T-bet and Bcl-6 collaborate to regulate Th1 gene expression patterns. J. Exp. Med 208, 1001-1013 (2011). [PubMed: 21518797]

47. Iwata $\mathrm{S}$ et al. The transcription factor T-bet limits amplification of type I IFN transcriptome and circuitry in T helper 1 cells. Immunity 46, 983-991 (2017). [PubMed: 28623086]

48. Kao C et al. Transcription factor T-bet represses expression of the inhibitory receptor PD-1 and sustains virus-specific CD8 $+\mathrm{T}$ cell responses during chronic infection. Nat. Immunol 12, 663-671 (2011). [PubMed: 21623380]

49. Anderson AC et al. T-bet, a Th1 transcription factor regulates the expression of Tim-3. Eur. J. Immunol 40, 859-866 (2010). [PubMed: 20049876]

50. Schulz EG, Mariani L, Radbruch A \& Hofer T Sequential polarization and imprinting of type $1 \mathrm{~T}$ helper lymphocytes by interferon-gamma and interleukin-12. Immunity 30, 673-683 (2009). [PubMed: 19409816]

51. Afkarian $\mathrm{M}$ et al. T-bet is a STAT1-induced regulator of IL-12R expression in naive CD4 + T cells. Nat. Immunol 3, 549-557 (2002). [PubMed: 12006974]

52. Stienne $\mathrm{C}$ et al. Foxo3 transcription factor drives pathogenic $\mathrm{T}$ helper 1 differentiation by inducing the expression of Eomes. Immunity 45, 774-787 (2016). [PubMed: 27742544]

53. Mullen AC et al. Role of T-bet in commitment of TH1 cells before IL-12-dependent selection. Science 292, 1907-1910 (2001). [PubMed: 11397944]

54. Joshi NS et al. Inflammation directs memory precursor and short-lived effector CD8(+) T cell fates via the graded expression of T-bet transcription factor. Immunity 27, 281-295 (2007). [PubMed: 17723218]

55. Yin $\mathrm{Z}$ et al. T-bet expression and failure of GATA-3 cross-regulation lead to default production of IFN-gamma by gammadelta T cells. J. Immunol 168, 1566-1571 (2002). [PubMed: 11823483]

56. Lugo-Villarino G, Maldonado-Lopez R, Possemato R, Penaranda C \& Glimcher LH T-bet is required for optimal production of IFN-gamma and antigen-specific $\mathrm{T}$ cell activation by dendritic cells. Proc. Natl Acad. Sci. USA 100, 7749-7754 (2003). [PubMed: 12802010]

57. Lugo-Villarino G, Ito S, Klinman DM \& Glimcher LH The adjuvant activity of CpG DNA requires T-bet expression in dendritic cells. Proc. Natl Acad. Sci. USA 102, 13248-13253 (2005). [PubMed: 16135562]

58. Klose CS et al. Differentiation of type 1 ILCs from a common progenitor to all helper-like innate lymphoid cell lineages. Cell 157, 340-356 (2014). [PubMed: 24725403]

59. Kwong B et al. T-bet-dependent NKp46 innate lymphoid cells regulate the onset of TH17-induced neuroinflammation. Nat. Immunol 18, 1117-1127 (2017). [PubMed: 28805812]

60. Powell $\mathrm{N}$ et al. The transcription factor T-bet regulates intestinal inflammation mediated by interleukin-7 receptor + innate lymphoid cells. Immunity 37, 674-684 (2012). [PubMed: 23063332]

61. Takeda A et al. Cutting edge: role of IL-27/WSX-1 signaling for induction of T-bet through activation of STAT1 during initial Th1 commitment. J. Immunol 170, 4886-4890 (2003). [PubMed: 12734330]

62. Sutherland AP et al. IL-21 promotes CD8 $8_{+}$CTL activity via the transcription factor T-bet. J. Immunol 190, 3977-3984 (2013). [PubMed: 23479229] 
63. Wiesel $\mathrm{M}$ et al. Type-I IFN drives the differentiation of short-lived effector $\mathrm{CD} 8_{+} \mathrm{T}$ cells in vivo. Eur. J. Immunol 42, 320-329 (2012). [PubMed: 22102057]

64. Chornoguz $\mathrm{O}$ et al. mTORC1 promotes T-bet phosphorylation to regulate Th1 differentiation. J. Immunol 198, 3939-3948 (2017). [PubMed: 28424242]

65. Oh S \& Hwang ES The role of protein modifications of T-bet in cytokine production and differentiation of T helper cells. J. Immunol. Res 2014, 589672 (2014). [PubMed: 24901011]

66. McLane LM et al. Differential localization of T-bet and Eomes in CD8 T cell memory populations. J. Immunol 190, 3207-3215 (2013). [PubMed: 23455505]

67. Chang JT et al. Asymmetric proteasome segregation as a mechanism for unequal partitioning of the transcription factor T-bet during T lymphocyte division. Immunity 34, 492-504 (2011). [PubMed: 21497118]

68. Neurath MF et al. The transcription factor T-bet regulates mucosal T cell activation in experimental colitis and Crohn's disease. J. Exp. Med 195, 1129-1143 (2002). [PubMed: 11994418]

69. Jang EJ, Park HR, Hong JH \& Hwang ES Lysine 313 of T-box is crucial for modulation of protein stability, DNA binding, and threonine phosphorylation of T-bet. J. Immunol 190, 5764-5770 (2013). [PubMed: 23616576]

70. Zhu J et al. The transcription factor T-bet is induced by multiple pathways and prevents an endogenous Th2 cell program during Th1 cell responses. Immunity 37, 660-673 (2012). [PubMed: 23041064]

71. Beima KM et al. T-bet binding to newly identified target gene promoters is cell type-independent but results in variable context-dependent functional effects. J. Biol. Chem 281, 11992-12000 (2006). [PubMed: 16473879]

72. Jenner RG et al. The transcription factors T-bet and GATA-3 control alternative pathways of T cell differentiation through a shared set of target genes. Proc. Natl Acad. Sci. USA 106, 17876-17881 (2009). [PubMed: 19805038]

73. Dominguez CX et al. The transcription factors ZEB2 and T-bet cooperate to program cytotoxic T cell terminal differentiation in response to LCMV viral infection. J. Exp. Med 212, 2041-2056 (2015). [PubMed: 26503446]

74. Sullivan BM, Juedes A, Szabo SJ, von Herrath M \& Glimcher LH Antigen-driven effector CD8 T cell function regulated by T-bet. Proc. Natl Acad. Sci. USA 100, 15818-15823 (2003). [PubMed: 14673093]

75. Brewitz A et al. CD8(+ $)$ T cells orchestrate pDC-XCR1(+) dendritic cell spatial and functional cooperativity to optimize priming. Immunity 46, 205-219 (2017). [PubMed: 28190711]

76. Gerard A et al. Secondary T cell-T cell synaptic interactions drive the differentiation of protective CD8 T cells. Nat. Immunol 14, 356-363 (2013). [PubMed: 23475183]

77. Harms Pritchard G et al. Diverse roles for T-bet in the effector responses required for resistance to infection. J. Immunol 194, 1131-1140 (2015). [PubMed: 25556247]

78. Intlekofer AM et al. Requirement for T-bet in the aberrant differentiation of unhelped memory CD8+ T cells. J. Exp. Med 204, 2015-2021 (2007). [PubMed: 17698591]

79. Hu JK, Kagari T, Clingan JM \& Matloubian M Expression of chemokine receptor CXCR3 on T cells affects the balance between effector and memory CD8 T cell generation. Proc. Natl Acad. Sci. USA 108, E118-E127 (2011). [PubMed: 21518913]

80. Lord GM et al. T-bet is required for optimal proinflammatory CD4 $4_{+} \mathrm{T}$ cell trafficking. Blood 106, 3432-3439 (2005). [PubMed: 16014561]

81. Austrup F et al. P- and E-selectin mediate recruitment of T-helper-1 but not T-helper-2 cells into inflammed tissues. Nature 385, 81-83 (1997). [PubMed: 8985251]

82. Borges E et al. P-selectin glycoprotein ligand-1 (PSGL-1) on T helper 1 but not on T helper 2 cells binds to P-selectin and supports migration into inflamed skin. J. Exp. Med 185, 573-578 (1997). [PubMed: 9053457]

83. Kum WW et al. Lack of functional P-selectin ligand exacerbates Salmonella serovar typhimurium infection. J. Immunol 182, 6550-6561 (2009). [PubMed: 19414810]

84. Lindell DM, Lane TE \& Lukacs NW CXCL10/CXCR3-mediated responses promote immunity to respiratory syncytial virus infection by augmenting dendritic cell and CD8(+ $)$ T cell efficacy. Eur. J. Immunol 38, 2168-2179 (2008). [PubMed: 18624292] 
85. Cohen SB et al. CXCR3-dependent CD4(+) T cells are required to activate inflammatory monocytes for defense against intestinal infection. PLOS Pathog. 9, e1003706 (2013). [PubMed: 24130498]

86. Wilson DC, Matthews S \& Yap GS IL-12 signaling drives CD8 $8_{+}$T cell IFN-gamma production and differentiation of KLRG1 + effector subpopulations during Toxoplasma gondii Infection. J. Immunol 180, 5935-5945 (2008). [PubMed: 18424713]

87. Shah S, Grotenbreg GM, Rivera A \& Yap GS An extrafollicular pathway for the generation of effector CD8(+) T cells driven by the proinflammatory cytokine, IL-12. eLife 4, e09017 (2015).

88. Jaakkola I, Merinen M, Jalkanen S \& Hanninen A Ly6C induces clustering of LFA-1 (CD11a/ CD18) and is involved in subtype-specific adhesion of CD8 T cells. J. Immunol 170, 1283-1290 (2003). [PubMed: 12538687]

89. Cai D et al. Mechanical feedback through E-cadherin promotes direction sensing during collective cell migration. Cell 157, 1146-1159 (2014). [PubMed: 24855950]

90. Hanninen A, Jaakkola I, Salmi M, Simell O \& Jalkanen S Ly-6C regulates endothelial adhesion and homing of CD8(+) T cells by activating integrin-dependent adhesion pathways. Proc. Natl Acad. Sci. USA 94, 6898-6903 (1997). [PubMed: 9192663]

91. Hall AO et al. The cytokines interleukin 27 and interferon-gamma promote distinct Treg cell populations required to limit infection-induced pathology. Immunity 37, 511-523 (2012). [PubMed: 22981537]

92. Oldenhove $\mathrm{G}$ et al. Decrease of Foxp3 $3_{+}$Treg cell number and acquisition of effector cell phenotype during lethal infection. Immunity 31, 772-786 (2009). [PubMed: 19896394]

93. Koch MA et al. The transcription factor T-bet controls regulatory $\mathrm{T}$ cell homeostasis and function during type 1 inflammation. Nat. Immunol 10, 595-602 (2009). [PubMed: 19412181]

94. Levine AG et al. Stability and function of regulatory T cells expressing the transcription factor Tbet. Nature 546, 421-425 (2017). [PubMed: 28607488]

95. Sciume $\mathrm{G}$ et al. Distinct requirements for T-bet in gut innate lymphoid cells. J. Exp. Med 209, 2331-2338 (2012). [PubMed: 23209316]

96. Townsend MJ et al. T-bet regulates the terminal maturation and homeostasis of NK and Valpha14i NKT cells. Immunity 20, 477-494 (2004). [PubMed: 15084276]

97. Silver JS et al. Inflammatory triggers associated with exacerbations of COPD orchestrate plasticity of group 2 innate lymphoid cells in the lungs. Nat. Immunol 17, 626-635 (2016). [PubMed: 27111143]

98. Gordon SM et al. The transcription factors T-bet and Eomes control key checkpoints of natural killer cell maturation. Immunity 36, 55-67 (2012). [PubMed: 22261438]

99. Jenne $\mathrm{CN}$ et al. T-bet-dependent S1P5 expression in NK cells promotes egress from lymph nodes and bone marrow. J. Exp. Med 206, 2469-2481 (2009). [PubMed: 19808259]

100. Mayol K, Biajoux V, Marvel J, Balabanian K \& Walzer T Sequential desensitization of CXCR4 and S1P5 controls natural killer cell trafficking. Blood 118, 4863-4871 (2011). [PubMed: 21911833]

101. Fang V et al. Gradients of the signaling lipid S1P in lymph nodes position natural killer cells and regulate their interferon-gamma response. Nat. Immunol 18, 15-25 (2017). [PubMed: 27841869]

102. Scott P, Natovitz P, Coffman RL, Pearce E \& Sher A Immunoregulation of cutaneous leishmaniasis. $\mathrm{T}$ cell lines that transfer protective immunity or exacerbation belong to different $\mathrm{T}$ helper subsets and respond to distinct parasite antigens. J. Exp. Med 168, 1675-1684 (1988). [PubMed: 2903212]

103. Locksley RM, Heinzel FP, Sadick MD, Holaday BJ \& Gardner KD Jr. Murine cutaneous leishmaniasis: susceptibility correlates with differential expansion of helper T cell subsets. Ann. Inst. Pasteur Immunol 138, 744-749 (1987).

104. Cooper AM et al. Disseminated tuberculosis in interferon gamma gene-disrupted mice. J. Exp. Med 178, 2243-2247 (1993). [PubMed: 8245795]

105. Hess J, Ladel C, Miko D \& Kaufmann SH Salmonella typhimurium aroA- infection in genetargeted immunodeficient mice: major role of CD4 + TCR-alpha beta cells and IFN-gamma in bacterial clearance independent of intracellular location. J. Immunol 156, 3321-3326 (1996). [PubMed: 8617956] 
106. Sullivan BM et al. Increased susceptibility of mice lacking T-bet to infection with Mycobacterium tuberculosis correlates with increased IL-10 and decreased IFN-gamma production. J. Immunol 175, 4593-4602 (2005). [PubMed: 16177104]

107. Ravindran R, Foley J, Stoklasek T, Glimcher LH \& McSorley SJ Expression of T-bet by CD4 T cells is essential for resistance to Salmonella infection. J. Immunol 175, 4603-4610 (2005). [PubMed: 16177105]

108. Way SS \& Wilson CB Cutting edge: immunity and IFN-gamma production during Listeria monocytogenes infection in the absence of T-bet. J. Immunol 173, 5918-5922 (2004). [PubMed: 15528324]

109. Ou R, Zhou S, Huang L \& Moskophidis D Critical role for alpha/beta and gamma interferons in persistence of lymphocytic choriomeningitis virus by clonal exhaustion of cytotoxic T cells. $\mathrm{J}$. Virol 75, 8407-8423 (2001). [PubMed: 11507186]

110. Intlekofer AM et al. Anomalous type 17 response to viral infection by $\mathrm{CD} 8_{+} \mathrm{T}$ cells lacking T-bet and eomesodermin. Science 321, 408-411 (2008). [PubMed: 18635804]

111. Nayar R et al. IRF4 regulates the ratio of T-Bet to eomesodermin in CD8 $+\mathrm{T}$ cells responding to persistent LCMV infection. PLOS ONE 10, e0144826 (2015). [PubMed: 26714260]

112. Smith A et al. The role of the integrin LFA-1 in T-lymphocyte migration. Immunol. Rev 218 , 135-146 (2007). [PubMed: 17624950]

113. Harris TH et al. Generalized Levy walks and the role of chemokines in migration of effector CD8 + T cells. Nature 486, 545-548 (2012). [PubMed: 22722867]

114. Oakley MS et al. The transcription factor T-bet regulates parasitemia and promotes pathogenesis during Plasmodium berghei ANKA murine malaria. J. Immunol 191, 4699-4708 (2013). [PubMed: 24078698]

115. Guo S, Cobb D \& Smeltz RB T-bet inhibits the in vivo differentiation of parasite-specific CD4 $4_{+}$ Th17 cells in a T cell-intrinsic manner. J. Immunol 182, 6179-6186 (2009). [PubMed: 19414771]

116. Cobb D et al. T-Bet-dependent regulation of $\mathrm{CD} 8_{+} \mathrm{T}$ cell expansion during experimental Trypanosoma cruzi infection. Immunology 128, 589-599 (2009). [PubMed: 19824916]

117. da Matta Guedes PM et al. IL-17 produced during Trypanosoma cruzi infection plays a central role in regulating parasite-induced myocarditis. PLOS Negl. Trop. Dis 4, e604 (2010). [PubMed: 20169058]

118. Miyazaki Y et al. IL-17 is necessary for host protection against acute-phase Trypanosoma cruzi infection. J. Immunol 185, 1150-1157 (2010). [PubMed: 20562260]

119. Er JZ, Koean RAG \& Ding JL Loss of T-bet confers survival advantage to influenza-bacterial superinfection. EMBO J. 38, e99176 (2019). [PubMed: 30322895]

120. Skyberg JA et al. Interleukin-17 protects against the Francisella tularensis live vaccine strain but not against a virulent F. tularensis type A strain. Infect. Immun 81, 3099-3105 (2013). [PubMed: 23774604]

121. Melillo AA, Foreman O, Bosio CM \& Elkins KL T-bet regulates immunity to Francisella tularensis live vaccine strain infection, particularly in lungs. Infect. Immun 82, 1477-1490 (2014). [PubMed: 24421047]

122. Garrett WS et al. Communicable ulcerative colitis induced by T-bet deficiency in the innate immune system. Cell 131, 33-45 (2007). [PubMed: 17923086]

123. Torrado $\mathrm{E}$ et al. Interleukin $27 \mathrm{R}$ regulates $\mathrm{CD} 4_{+} \mathrm{T}$ cell phenotype and impacts protective immunity during Mycobacterium tuberculosis infection. J. Exp. Med 212, 1449-1463 (2015). [PubMed: 26282876]

124. Sallin MA et al. Th1 differentiation drives the accumulation of intravascular, non-protective CD4 T cells during tuberculosis. Cell. Rep 18, 3091-3104 (2017). [PubMed: 28355562]

125. Sato F et al. T-bet, but not Gata3, overexpression is detrimental in a neurotropic viral infection. Sci. Rep 7, 10496 (2017). [PubMed: 28874814]

126. Weinstein JS et al. STAT4 and T-bet control follicular helper T cell development in viral infections. J. Exp. Med 215, 337-355 (2018). [PubMed: 29212666]

127. Fang $\mathrm{D}$ et al. Transient T-bet expression functionally specifies a distinct $\mathrm{T}$ follicular helper subset. J. Exp. Med 215, 2705 (2018). [PubMed: 30232200] 
128. Peng SL, Szabo SJ \& Glimcher LH T-bet regulates IgG class switching and pathogenic autoantibody production. Proc. Natl Acad. Sci. USA 99, 5545-5550 (2002). [PubMed: 11960012]

129. Gerth AJ, Lin L \& Peng SL T-bet regulates T-independent IgG2a class switching. Int. Immunol 15, 937-944 (2003). [PubMed: 12882831]

130. Xu W \& Zhang JJ Stat1-dependent synergistic activation of T-bet for IgG2a production during early stage of B cell activation. J. Immunol 175, 7419-7424 (2005). [PubMed: 16301649]

131. Liu N, Ohnishi N, Ni L, Akira S \& Bacon KB CpG directly induces T-bet expression and inhibits IgG1 and IgE switching in B cells. Nat. Immunol 4, 687-693 (2003). [PubMed: 12766768]

132. Rubtsova K, Rubtsov AV, Cancro MP \& Marrack P Age-associated B cells: a T-betdependent effector with roles in protective and pathogenic immunity. J. Immunol 195, 1933-1937 (2015). [PubMed: 26297793]

133. Naradikian MS et al. Cutting edge: IL-4, IL-21, and IFN-gamma interact to govern T-bet and CD11c expression in TLR-activated B cells. J. Immunol 197, 1023-1028 (2016). [PubMed: 27430719]

134. Wang NS et al. Divergent transcriptional programming of class-specific B cell memory by T-bet and RORalpha. Nat. Immunol 13, 604-611 (2012). [PubMed: 22561605]

135. Piovesan D et al. c-Myb regulates the T-bet-dependent differentiation program in B cells to coordinate antibody responses. Cell. Rep 19, 461-470 (2017). [PubMed: 28423310]

136. Mohr E et al. IFN-\{gamma\} produced by CD8 T cells induces T-bet-dependent and -independent class switching in B cells in responses to alum-precipitated protein vaccine. Proc. Natl Acad. Sci. USA 107, 17292-17297 (2010). [PubMed: 20855629]

137. Karnell JL et al. Role of CD11c(+) T-bet(+) B cells in human health and disease. Cell. Immunol 321, 40-45 (2017). [PubMed: 28756897]

138. Naradikian MS, Hao Y \& Cancro MP Age-associated B cells: key mediators of both protective and autoreactive humoral responses. Immunol. Rev 269, 118-129 (2016). [PubMed: 26683149]

139. Barnett BE et al. Cutting edge: B cell-intrinsic T-bet expression is required to control chronic viral infection. J. Immunol 197, 1017-1022 (2016). [PubMed: 27430722]

140. Knox JJ et al. T-bet + B cells are induced by human viral infections and dominate the HIV gp140 response. JCI Insight 2, 92943 (2017). [PubMed: 28422752]

141. Chang LY, Li Y \& Kaplan DE Hepatitis C viraemia reversibly maintains subset of antigenspecific T-bet + tissue-like memory B cells. J. Viral Hepat 24, 389-396 (2017). [PubMed: 27925349]

142. Kurktschiev PD et al. Dysfunctional CD8 $+\mathrm{T}$ cells in hepatitis B and C are characterized by a lack of antigen-specific T-bet induction. J. Exp. Med 211, 2047-2059 (2014). [PubMed: 25225458]

143. Hersperger AR et al. Increased HIV-specific CD8 $+\mathrm{T}$ cell cytotoxic potential in HIV elite controllers is associated with T-bet expression. Blood 117, 3799-3808 (2011). [PubMed: 21289310]

144. Ribeiro-dos-Santos P et al. Chronic HIV infection affects the expression of the 2 transcription factors required for CD8 T cell differentiation into cytolytic effectors. Blood 119, 4928-4938 (2012). [PubMed: 22490682]

145. Buggert $\mathrm{M}$ et al. T-bet and Eomes are differentially linked to the exhausted phenotype of CD8 $8_{+} \mathrm{T}$ cells in HIV infection. PLOS Pathog. 10, e1004251 (2014). [PubMed: 25032686]

146. Marshall HD et al. Differential expression of Ly6C and T-bet distinguish effector and memory Th1 CD4(+) cell properties during viral infection. Immunity 35, 633-646 (2011). [PubMed: 22018471]

147. Pearce EL \& Shen H Generation of CD8 T cell memory is regulated by IL-12. J. Immunol 179, 2074-2081 (2007). [PubMed: 17675465]

148. Darrah PA et al. Multifunctional TH1 cells define a correlate of vaccine-mediated protection against Leishmania major. Nat. Med 13, 843-850 (2007). [PubMed: 17558415]

149. Paley MA et al. Progenitor and terminal subsets of $\mathrm{CD} 8_{+} \mathrm{T}$ cells cooperate to contain chronic viral infection. Science 338, 1220-1225 (2012). [PubMed: 23197535] 
150. Hoffmann M et al. Exhaustion of activated CD8 T cells predicts disease progression in primary HIV-1 infection. PLOS Pathog. 12, e1005661 (2016). [PubMed: 27415828]

151. Mackay LK et al. T-box transcription factors combine with the cytokines TGF-beta and IL-15 to control tissue-resident memory T cell fate. Immunity 43, 1101-1111 (2015). [PubMed: 26682984]

152. Klarquist $\mathrm{J}$ et al. Clonal expansion of vaccine-elicited $\mathrm{T}$ cells is independent of aerobic glycolysis. Sci. Immunol 3, eaas9822 (2018). [PubMed: 30194241]

153. Jameson SC \& Masopust D Diversity in T cell memory: an embarrassment of riches. Immunity 31, 859-871 (2009). [PubMed: 20064446]

154. Olson JA, McDonald-Hyman C, Jameson SC \& Hamilton SE Effector-like CD8(+) T cells in the memory population mediate potent protective immunity. Immunity 38, 1250-1260 (2013). [PubMed: 23746652]

155. Snyder CM et al. Memory inflation during chronic viral infection is maintained by continuous production of short-lived, functional T cells. Immunity 29, 650-659 (2008). [PubMed: 18957267]

156. Chu $\mathrm{HH}$ et al. Continuous effector $\mathrm{CD} 8\left(_{+}\right) \mathrm{T}$ cell production in a controlled persistent infection is sustained by a proliferative intermediate population. Immunity 45, 159-171 (2016). [PubMed: 27421704]

157. Bottcher JP et al. Functional classification of memory CD8(++ T cells by CX3CR1 expression. Nat. Commun 6, 8306 (2015). [PubMed: 26404698]

158. Gerlach $\mathrm{C}$ et al. The chemokine receptor CX3CR1 defines three antigen-experienced CD8 T cell subsets with distinct roles in immune surveillance and homeostasis. Immunity 45, 1270-1284 (2016). [PubMed: 27939671]

159. Herndler-Brandstetter D et al. KLRG1(+) effector CD8(+) T cells lose KLRG1, differentiate into all memory $\mathrm{T}$ cell lineages, and convey enhanced protective immunity. Immunity 48, 716-729 (2018). [PubMed: 29625895]

160. Diaz YR, Rojas R, Valderrama L \& Saravia NG T-bet, GATA-3, and Foxp3 expression and Th1/Th2 cytokine production in the clinical outcome of human infection with Leishmania (Viannia) species. J. Infect. Dis 202, 406-415 (2010). [PubMed: 20583921]

161. Dorfman DM, Hwang ES, Shahsafaei A \& Glimcher LH T-bet, a T cell-associated transcription factor, is expressed in Hodgkin's lymphoma. Hum. Pathol 36, 10-15 (2005). [PubMed: 15712176]

162. Dorfman DM, Hwang ES, Shahsafaei A \& Glimcher LH T-bet, a T cell-associated transcription factor, is expressed in a subset of B cell lymphoproliferative disorders. Am. J. Clin. Pathol 122, 292-297 (2004). [PubMed: 15323146]

163. Dorfman DM, van den Elzen P, Weng AP, Shahsafaei A \& Glimcher LH Differential expression of T-bet, a T-box transcription factor required for Th1 T cell development, in peripheral T cell lymphomas. Am. J. Clin. Pathol 120, 866-873 (2003). [PubMed: 14671975]

164. Dolfi DV et al. Increased T-bet is associated with senescence of influenza virus-specific CD8 T cells in aged humans. J. Leukoc. Biol 93, 825-836 (2013). [PubMed: 23440501]

165. Sasaki $\mathrm{Y}$ et al. Identification of a novel type 1 diabetes susceptibility gene. T-bet. Hum. Genet 115, 177-184 (2004). [PubMed: 15241679]

166. Svensson A et al. A $3^{\prime}$-untranslated region polymorphism in the TBX21 gene encoding T-bet is a risk factor for genital herpes simplex virus type 2 infection in humans. J. Gen. Virol 89, 22622268 (2008). [PubMed: 18753235]

167. vensson A, Nordstrom I, Sun JB \& Eriksson K Protective immunity to genital herpes simplex [correction of simpex] virus type 2 infection is mediated by T-bet. J. Immunol 174, 6266-6273 (2005). [PubMed: 15879125] 


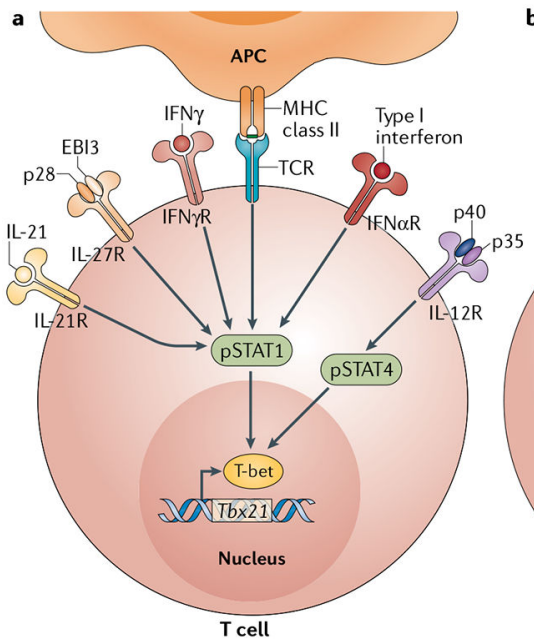

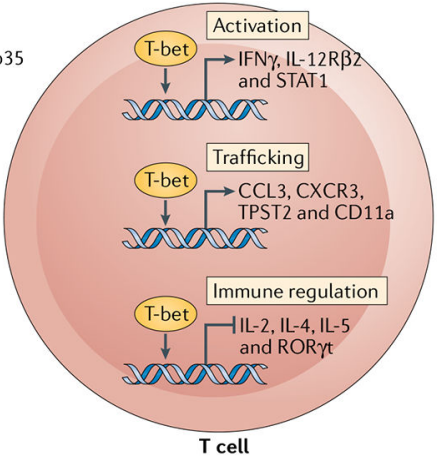

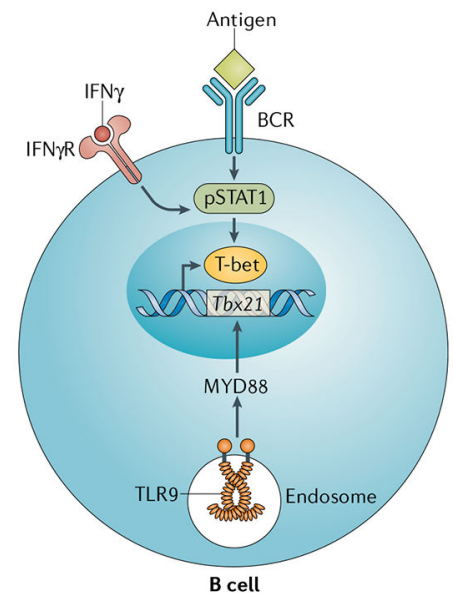

Fig. 1 . The induction and diverse target genes of T-bet.

a T-bet is induced in T cells through signal transducer and activator of transcription 1 (STAT1) downstream of T cell receptor (TCR) signalling and/or signalling through IFN $\gamma \mathrm{R}$, IFNaR, IL-27R and IL-21R. T-bet is also induced through STAT4 downstream of signalling through IL-12R. b | After T-bet is induced, it binds to an array of genes that exert diverse functions in the cell including activation (via IFN $\gamma$, IL12R $\beta 2$ and STAT1), cellular trafficking (via CC-chemokine ligand 3 (CCL3), CXC-chemokine receptor 3 (CXCR3), tyrosyl protein sulfotransferase 2 (TPST2) and CD11a) and immune regulation (via IL-2, IL-4, IL-5 and ROR $\gamma \mathrm{t}$ ). $\mathbf{c}$ | T-bet is induced in B cells through STAT1 after ligation of the B cell receptor $(\mathrm{BCR})$ and/or IFN $\gamma \mathrm{R}$. T-bet can also be induced through MYD88 downstream of Toll-like receptor 9 (TLR9) signalling. pSTAT, phosphorylated STAT. APC, antigenpresenting cell. 


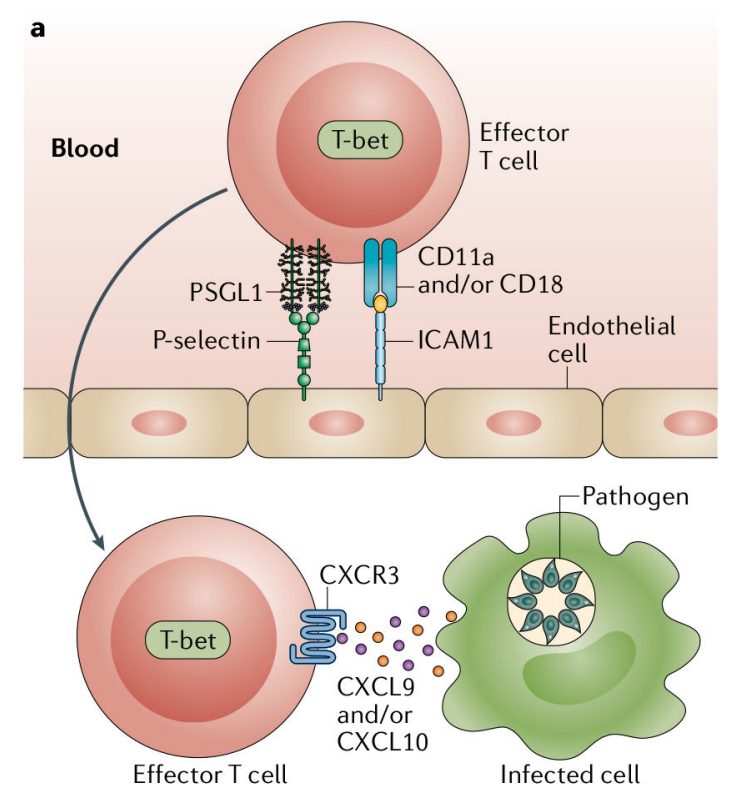

b

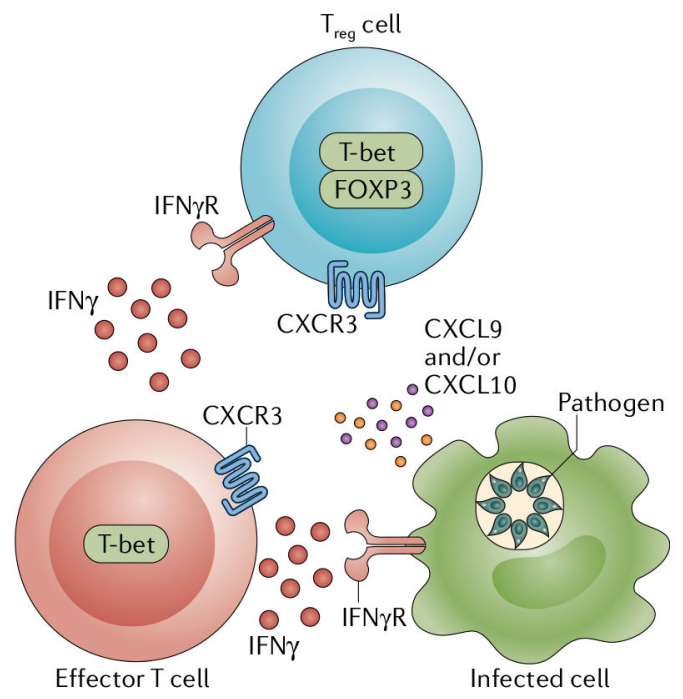

Fig. 2 |. Expression of T-bet is linked to $\mathbf{T}$ cell trafficking behaviour.

a T-bet activation is associated with the increased expression of CD11a as well as the expression of enzymes that promote the glycosylation of P-selectin glycoprotein ligand 1 (PSGL1) and its binding to P-selectin, which is required for T cell adhesion to inflamed endothelium and migration into sites of inflammation. Within these tissues, T-bet-mediated expression of CXC-chemokine receptor 3 (CXCR3) enables T cells to respond to IFN $\gamma$ induced chemokines, such as CXC-chemokine ligand 9 (CXCL9) and CXCL10, and thus mediate local control of infections in tissues. $\mathbf{b} \mid$ The coordinated expression of T-bet by effector $\mathrm{T}$ cell and regulatory $\mathrm{T}\left(\mathrm{T}_{\text {reg }}\right)$ cell populations would enable these cell types to respond to similar environmental signals and ensure that the regulatory mechanisms mediated by $\mathrm{T}_{\text {reg }}$ cells occur at sites of $\mathrm{T}$ helper $1\left(\mathrm{~T}_{\mathrm{H}} 1\right)$ cell-like inflammation. Whether $\mathrm{T}$ bet acts in concert with forkhead box P3 (FOXP3) to engage distinct regulatory mechanisms that are required to limit local inflammation is uncertain. 

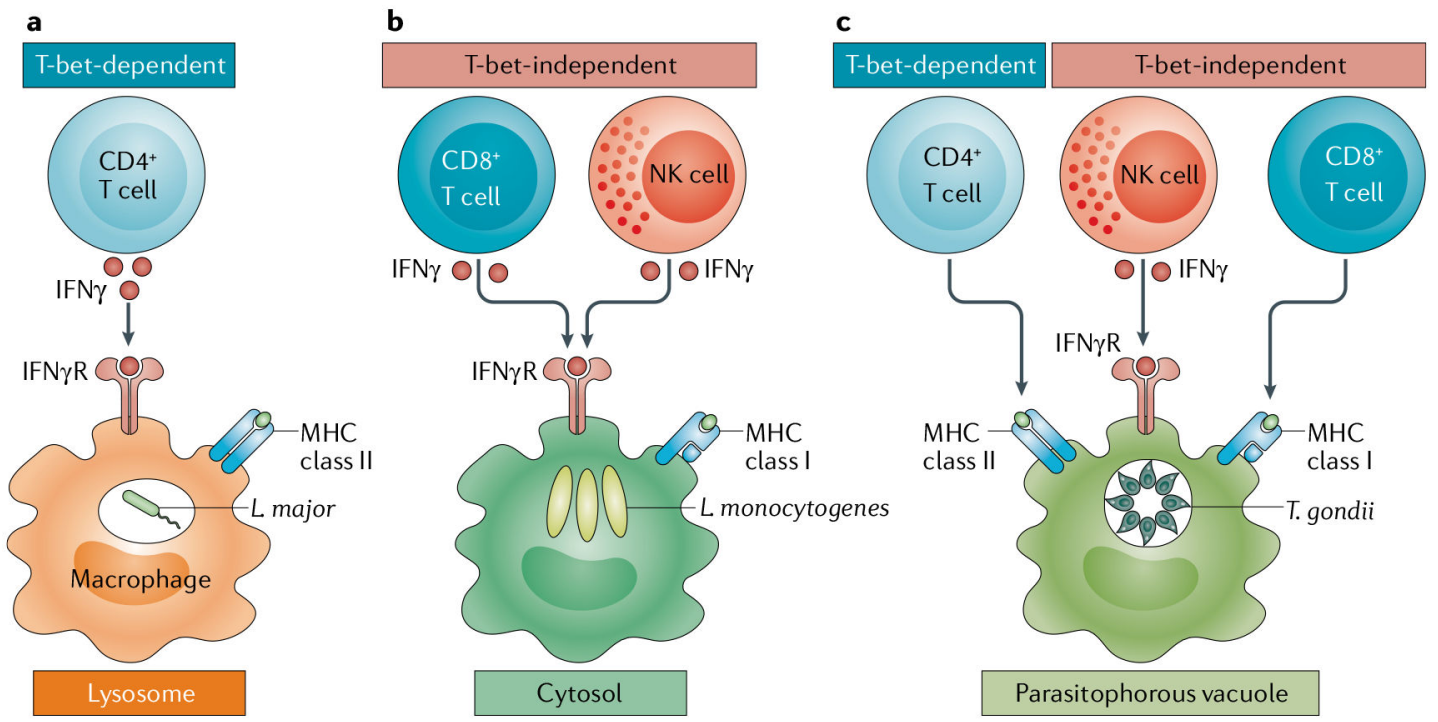

Fig. 3 |. T-bet in immunity to pathogens that occupy distinct intracellular niches.

a Pathogens such as Leishmania major are specialized to survive and replicate inside the phagolysosomal system. Microbial antigens at these sites drive the development of MHC class II-restricted T-bet-dependent $\mathrm{CD}^{+}{ }^{+} \mathrm{T}$ cells, and the production of IFN $\gamma$ by these cells is the dominant pathway that mediates parasite control. $\mathbf{b} \mid$ The ability to escape from the phagolysosomal system into the cytosol of host cells provides a mechanism for Listeria monocytogenes to avoid killing, but in this compartment, bacterial antigens are readily presented to $\mathrm{MHC}$ class I-restricted $\mathrm{CD}^{+} \mathrm{T}$ cells. In addition, innate responses mediated by natural killer (NK) cells also contribute to the production of IFN $\gamma$. c $\mid$ Toxoplasma gondii replicates in a unique parasitophorous vacuole that does not fuse with the lysosomal compartment but fully engages innate and adaptive production of IFN $\gamma$. While the ability to generate parasite-specific $\mathrm{CD} 4^{+} \mathrm{T}$ cells is partially dependent on T-bet, the magnitude of the NK cell and $\mathrm{CD}^{+}$cell response appears intact in the absence of T-bet. 


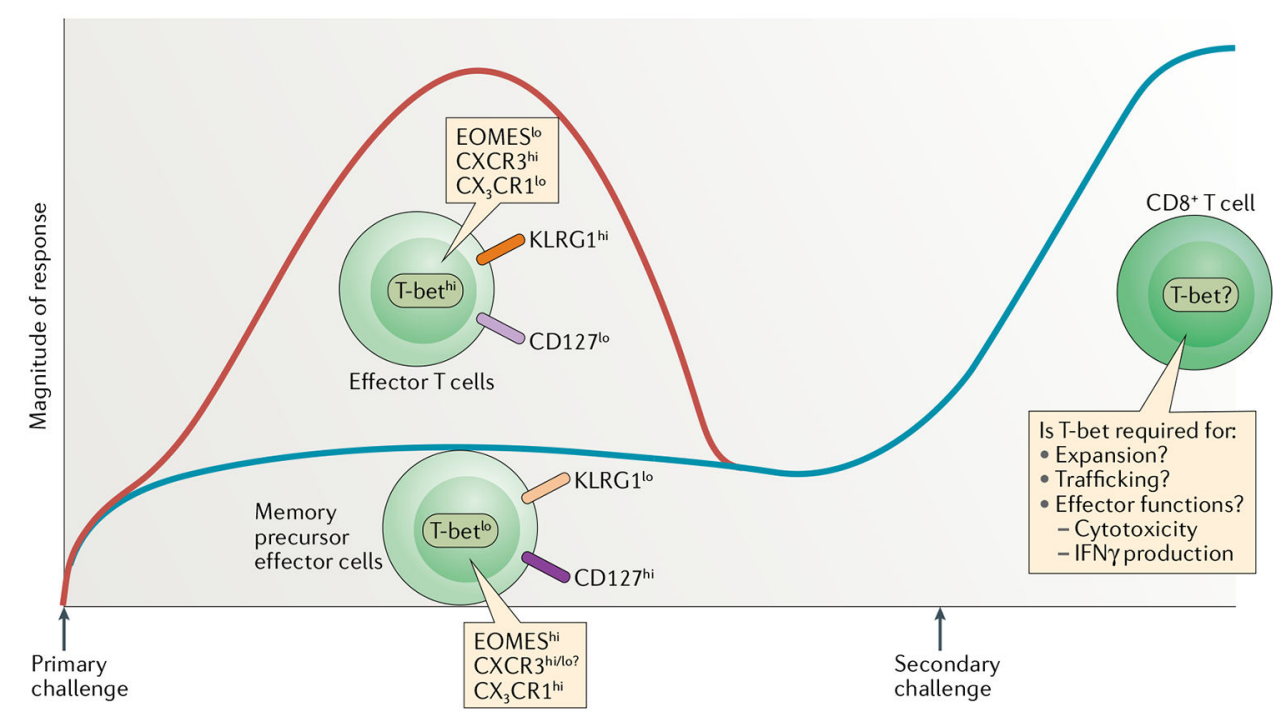

Fig. 4 |. Differential expression and function of T-bet and EOMES during differentiation of effector and memory $T$ cell subsets.

A primary immune challenge results in the activation and expansion of pathogen-specific $\mathrm{CD}^{+} \mathrm{T}$ cell populations that give rise to distinct populations of memory precursors as well as effector cells. The relative levels of T-bet and eomesodermin (EOMES) differ in these populations and may be influenced by levels of T cell receptor (TCR) engagement, the process of cell division and the inflammatory environment, factors which in turn influence the expression of surface molecules associated with distinct trafficking and effector functions. After resolution of infection, it is unclear how T-bet and EOMES influence memory responses to secondary challenges or, in the case of persistent infection, whether these transcription factors are required to maintain effective long-lived $\mathrm{T}$ cell responses. CX3CR1, CX3C-chemokine receptor 1; CXCR3, CXC-chemokine receptor 3; KLRG1, killer cell lectin-like receptor subfamily $\mathrm{G}$ member 1 . 


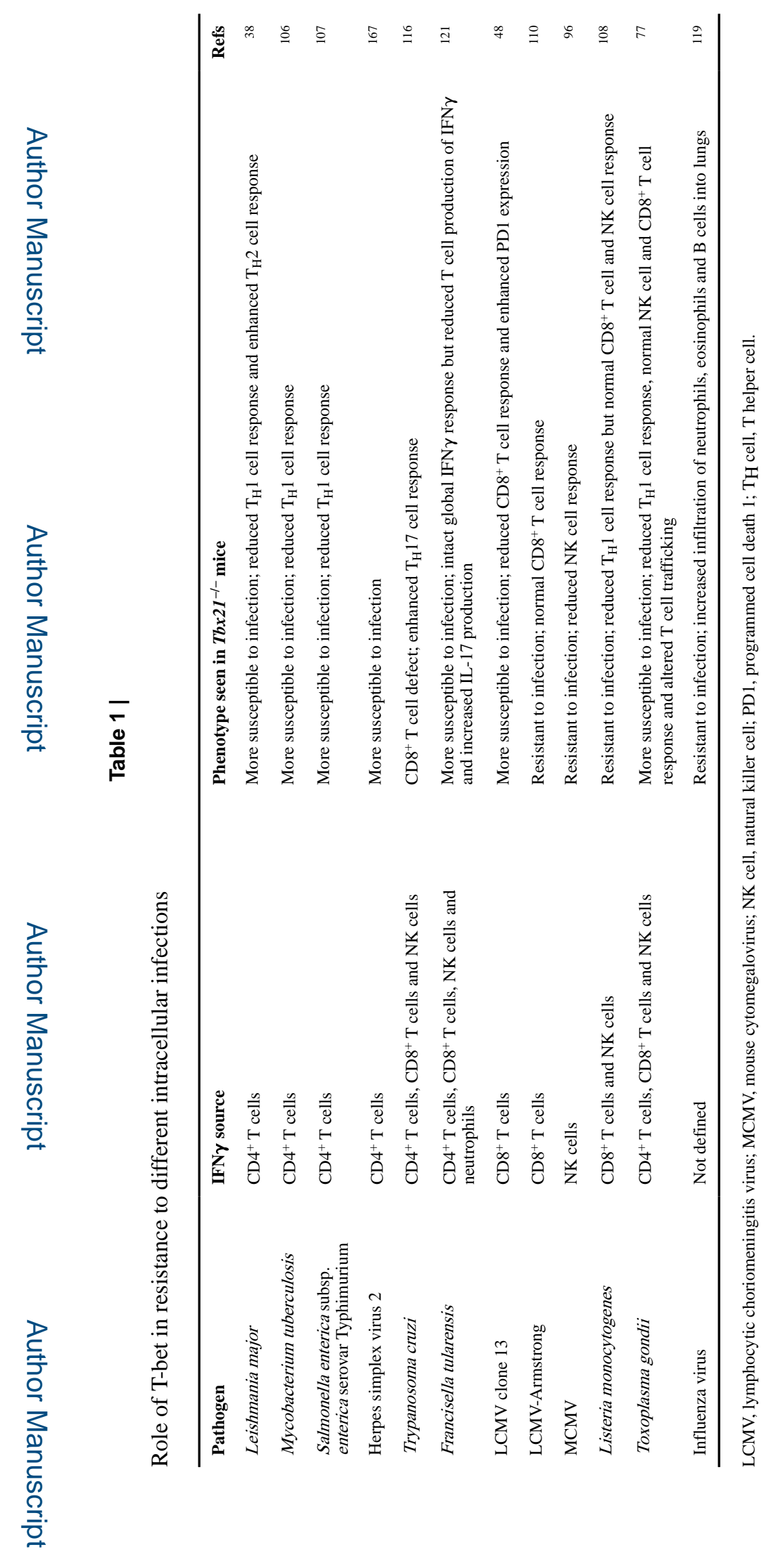

Nat Rev Immunol. Author manuscript; available in PMC 2020 June 04. 